\title{
Analysis of Multiple Queue Model in Cellular Networks with Sub Rating of Channels
}

\author{
Geetanjali Sharma*, G.N. Purohit* and Rakhee** \\ * Centre for Mathematical Sciences, Banasthali University, \\ Banasthali- 304022 and \\ **Birla Institute of Technology \& Sciences, Pilani-333013, India
}

\begin{abstract}
In cellular Networks we generally consider a single queue for each cell, some authors proposed a model with a dedicated queue for each transceiver in the cell. We have extended the idea of dedicated queue for each transceiver in the cell with sub-rating channels to improve the Quality of Service (QOS) of the system. In this paper we have compared three models, in model-I we used guard channels to give priority to handoff attempts and a buffer for finite size is provided to give priority to handoff data attempts, further in model-II we have taken sub-rating channel scheme (SCS). In subrating scheme a full rate channel is temporarily divided into two half rate channels in the blocked cell; one half rate channel serve the originating call and another serves handoff call. We proposed a dedicated queue for each transceiver in the cell with sub-rating in model-III. The Fixed Channel Assignment Scheme is considered for all models. The probabilities of handoff failure, blocking probability of new calls, forced termination of handoff calls, probability of noncompleted calls for all models are calculated for varying assumed of values arrival rate of new data calls, arrival rate of new voice calls, buffer size of channels and service rates. We compared and analyzed the numerical results to validate the proposed models.
\end{abstract}

Keywords: Handoff, Blocking probabilities, Queue, Cellular networks, Sub-rating.

\section{Introduction}

In the recent past, we have seen a remarkable growth of the mobile communication systems. The available frequency spectrum is limited and 
the number of mobile users is increasing day by day. The assignment of frequency spectrum to cells or mobiles is one of the fundamental resource management issues in a cellular radio networks. A very limited radio frequency spectrum is allocated to this service. So the frequency channels have to be reused as much as possible. The role of a channel assignment scheme is to allocate channels to cells or mobiles in such a way as to minimize the blocking probability i.e. the incoming calls are blocked in the cell.

A Cellular network comprises several base stations through which the wireless equipment is connected to the network. The radio coverage of each base station is called a cell. Within each cell, there are mainly two classes of call traffic: new call and handoff call. A new call is the one which is generated in the current cell, a new call does not enter service because of unavailability of channels then the call is blocked. A handoff call is one which is generated in another cell but transferred (handoff) to the current cell. When this call enters into the radio coverage of current cell, the channel allocation scheme decides whether a channel is available for this call, i.e. can it avail or not. If not, the call is dropped immediately. Once a channel has been assigned to a call, the channel will not be released until the call is over or handed over to another cell. The handoff process is often initiated either by crossing a cell boundary or by a deteriorated quality of signals in the currently employed channel.

In this paper three models are compared. We are using some channels reserved for handoff attempts in model-I, in model-II we use a sub-rating scheme. In the third model, we consider three dedicated queues at three transceivers (TRX) also consider sub-rating of guard channels for handoff voice calls at each queue. The probabilities of handoff failure, blocking probability of new calls, forced termination of handoff calls, probability of non-completed calls for all models are calculated for varying assumed values arrival rate of new data calls, arrival rate of new voice calls, buffer size of channels and service rates. We compared and analyzed the numerical results to validate the proposed models. The rest of the paper is organized as follows: Section 2 presents the three different models, and describes the assumptions made and notations adopted. The steady state queue size distribution is also obtained. Numerical discussion and results are included in section 3 and concluding remarks are given in section 4. 


\section{Literature Review}

Many channel assignment schemes such as Fixed Channel Assignment scheme (FCA), Dynamic Channel Assignment Scheme (DCA) and Hybrid Channel Assignment Scheme (HCA) have been proposed to assign frequencies to cells to maximize the frequency reuse. Radio spectrum resource is of fundamental importance in wireless communications. To improve the performance of mobile cellular networks, a novel scheme is presented by Amin and Islam ${ }^{[1]}$ by incorporating delay of voice end user to the new originating calls over handoff calls in a two dimensional traffic model. Beaubrun et al. ${ }^{\text {[2] }}$ presented a general model (i.e. $\mathrm{G} / \mathrm{G} / \mathrm{c} / \mathrm{c}$ queueing system) for teletraffic analysis in future wireless networks and found that coefficient of variation of call arrivals has more impact on the network performance than coefficient of variation of channel holding time and the system. Choi and Shin ${ }^{[3]}$ presented a predictive and adaptive scheme for bandwidth reservation and admission control that keeps the handoff dropping probability below a target value. Gavish and Sridhar [4] presented a policy called Threshold Priority Policy (TPP) for assigning channels in cellular networks and compared the performance of TPP with the performance of the well known Cut-off Priority Policy (CPP) and the Complete Sharing Policy (CSP). Guerrero and Aghvami ${ }^{[5]}$ proposed a dynamic channel allocation strategy called Compact Pattern with Maximized Channel Borrowing (CPMCB) which minimizes both the blocking rate of new calls and handoff failure rate. Hong and Rappaport [6] considered prioritized and non-prioritized schemes for channel assignment. Jain and Rakhee ${ }^{[7]}$ considered the sub-rating channel assignment scheme with directed retry to improve the performance of handoff packets, and quality of service (QOS) of cellular radio network and reduced blocking probabilities. Klienrock L. ${ }^{[8]}$ formulating models as well as developing operational formulas (exact or approximate) that may be used for analysis and design of systems. Li and Alpha ${ }^{[9]}$ generalized PCS network in which arrival of new calls are modeled by Markov Arrival Process (MAP), and there exists some channels which can be divided into two channels with different rates and obtained the new call blocking probability, forced termination probability of a handoff call and the mean dwell time. Lin and Lin ${ }^{[10]}$ proposed analytical and simulation models to study the performance of four channel assignment schemes 
(random, best fit, repacking, and fair-repacking) for GSM half-rate and full-rate traffic and conclude that the repacking scheme has the best performance for mixing half-rate and full-rate traffic. Lin et al. proposed a new personal communications services (PCS) hand-off scheme called sub-rating scheme. Their scheme reduces the force termination probability and carries more offered load compared with prioritized and non-prioritized schemes. $\mathrm{Li}$ and Joo ${ }^{[12]}$ presented Clustered Multi-hop Cellular Network architecture with the use of dedicated information ports (DIPs), which are deployed wireless ports functioning as central controllers for multi-hop users and study the feasibility of modeling time division multiple access (TDMA) based clustered multi-hop cellular network with fixed channel assignment (FCA) scheme for uplink transmission. Louvros et al. ${ }^{[13]}$ gave the priority to handover calls over new call attempts and blocked handover calls are placed in a finite storage queue and evaluated the total handover forced termination probability. Louvros et al. ${ }^{[14]}$ proposed a new traffic model with three different queues at each transceiver (TRX) per cell and compared their model with the model given by Hong and Rappaport ${ }^{[6]}$ and found that the blocking probabilities of new model are less than existing one. Milosh et al. ${ }^{[15]}$ focuses on three circuit allocation schemes for half and full rate connections in the Global system for mobile communications (GSM); best fit, repacking, and fair repacking and conclude that for traffic with full rate users, fair repacking is found to incur the lowest blocking probability and achieve best fairness, but when the traffic mix has no full rate users, best fit and repacking are better than fair repacking. A new admission control policy for wireless mobile multimedia networks is being proposed by Ojesanmi et al. ${ }^{[16]}$ which provides a QOS guarantee to both new and handoff calls and at the same time the exploitation of buffer resources to accommodate blocked handoff in order to improve the performance of the network. Tekinary and Jabbary ${ }^{[17]}$ proposed many channel assignment strategies for reusage of the same radio frequencies in non-interfering cells and proposed a method of prioritizing handover requests by queueing then in such a way that the one with the maximum probability of forced termination is served first. Ye et al. ${ }^{[18]}$ studied different predictive channel reservation schemes for cellular networks and evaluate the effect of the prereservation area size on handoff prioritization performance. 


\section{Models Description and Notation}

We consider a cellular network, where service area is divided into cells. Each cell has a base station and each base station having three transceivers (TRX). We assume that there are two types of traffic voice/data arriving according to Poisson Process. We have given priority to handoff calls over new calls.

To describe the model we use the following assumptions:

- The arrival of new voice (data) and handoff voice (data) calls attempts are generated according to a Poisson process with mean rates per cell of $\lambda_{\mathrm{nv}}\left(\lambda_{\mathrm{nd}}\right)$ and $\lambda_{\mathrm{hv}}\left(\lambda_{\mathrm{hd}}\right)$.

Denote

$$
\begin{aligned}
& \lambda_{\mathrm{n}}=\lambda_{\mathrm{nd}}+\lambda_{\mathrm{nv}} \\
& \lambda_{\mathrm{h}}=\lambda_{\mathrm{hd}}+\lambda_{\mathrm{hv}} \\
& \lambda=\lambda_{\mathrm{n}}+\lambda_{\mathrm{h}}
\end{aligned}
$$

- Approximate the channel holding time $\mathrm{T}_{\mathrm{H}}$ to have an exponential distribution with mean $\overline{\mathrm{T}_{\mathrm{H}}}\left(=\frac{1}{\mu_{\mathrm{H}}}\right)$

- The time a mobile terminal is in the handoff area (i.e. dwell time) $\mathrm{T}_{\mathrm{Q}}$ is exponentially distributed with mean $\overline{\mathrm{T}_{\mathrm{Q}}}\left(=\frac{1}{\mu_{\mathrm{Q}}}\right)$

- Each cell consists of $\mathrm{C}$ channels out of which $\mathrm{C}_{\mathrm{h}}$ channels are reserved to give priority for handoff calls.

Also define the probabilities

$\mathrm{P}_{0} \quad$ probability that there are no calls in the system.

$P_{j} \quad$ steady state probability of being $j$ calls in the system

$\mathrm{P}_{\mathrm{B}} \quad$ blocking probability of new calls.

$\mathrm{P}_{\mathrm{Bhv}}$ blocking probability of hand-off voice calls.

$\mathrm{P}_{\mathrm{fh}}$ handoff failure probability.

$\mathrm{P}_{\mathrm{F}} \quad$ force termination probability.

$\mathrm{P}_{\mathrm{nc}}$ probability that a call is not completed either due to blocking or forced termination.

$\mathrm{K}$ finite buffer size for handoff data request. 


\subsection{Model-I}

In this model, we assume that $\mathrm{C}$ channels are allocated to each cell. Priority is given to handoff call by providing $\mathrm{C}_{\mathrm{h}}$ channels as reserved channels to serve only handoff calls. Whenever less than $\mathrm{C}-\mathrm{C}_{\mathrm{h}}$ channels are occupied and new or handoff call arrive in the cell then a free channel is assigned to that call. If $\mathrm{C}-\mathrm{C}_{\mathrm{h}}$ or more than $\mathrm{C}-\mathrm{C}_{\mathrm{h}}$ channels are occupied then new calls are blocked and handoff calls are alloted a guard channel $\left(C_{h}\right)$ if available. If all the channels are busy then handoff data calls are queued in buffer of finite size $(\mathrm{K})$ or blocked due to buffer overflow.

Using the state transition diagram, as shown in Fig.1, we get the steady state probabilities, as given by the following set of difference equations:

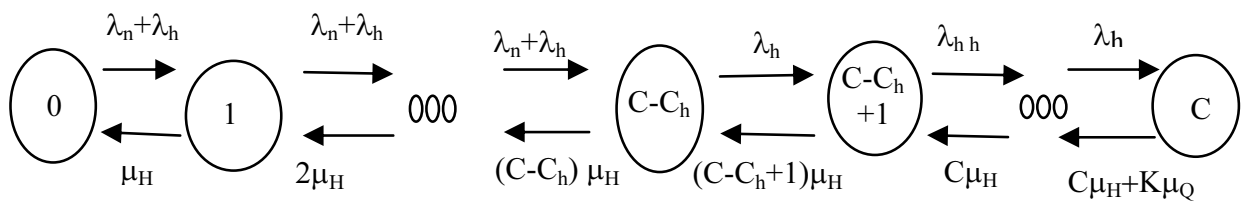

Fig. 1. Transition State Diagram for Model I.

$\mathrm{P}_{0}{ }^{\prime}(\mathrm{t})=-\left(\lambda_{\mathrm{n}}+\lambda_{\mathrm{h}}\right) \mathrm{P}_{0}(\mathrm{t})+\mu_{\mathrm{H}} \mathrm{P}_{1}(\mathrm{t})$

$P_{j}^{\prime}(t)=-\left\{\left(\lambda_{n}+\lambda_{h}\right)+j \mu_{H}\right\} P_{j}(t)+\left(\lambda_{n}+\lambda_{h}\right) P_{j-1}(t)+(j+1) \mu_{H} P_{j+1}(t), \quad, 0<j \leq C-C_{h}$

$P_{j}^{\prime}(t)=-\left(\lambda_{h}+j \mu_{H}\right) P_{j}(t)+\lambda_{h} P_{j-1}(t)+(j+1) \mu_{H} P_{j+1}(t), \quad, C-C_{h}+1 \leq j \leq C$

$\mathrm{P}_{\mathrm{j}}{ }^{\prime}(\mathrm{t})=-\left\{\lambda_{h d}+\left(\mathrm{C} \mu_{\mathrm{H}}+\mathrm{i} \mu_{\mathrm{Q}}\right)\right\} \mathrm{P}_{\mathrm{j}}+\lambda_{h d} \mathrm{P}_{\mathrm{j}-1}(\mathrm{t})+\left\{\mathrm{C} \mu_{\mathrm{H}}+(\mathrm{i}+1) \mu_{\mathrm{Q}}\right\} \mathrm{P}_{\mathrm{j}+1}(\mathrm{t}) \quad, \mathrm{C}+1<\mathrm{j} \leq \mathrm{C}+\mathrm{K}$

$, \mathrm{i}=1,2, \ldots \ldots \ldots \ldots, \mathrm{K}$

The steady state probabilities for the systems are derived assuming that $\mathrm{P}_{\mathrm{j}}(\mathrm{t})=\mathrm{P}_{\mathrm{j}}$, as $\mathrm{t} \rightarrow \infty$. The equations for steady state probabilities $\mathrm{P}_{\mathrm{j}}$, for $t \rightarrow \infty$ are obtained by putting $P_{j}{ }^{\prime}(t)=0$ and replacing $P_{j}(t)$ by $P_{j}$ in above equations. Thus, the difference equations become:

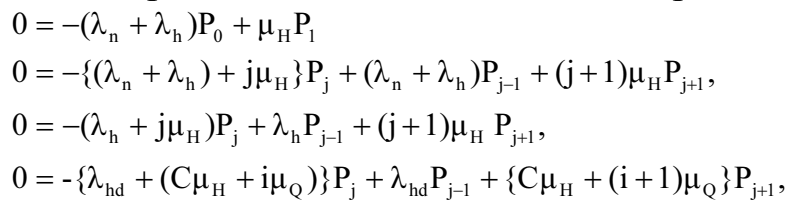

$$
\begin{aligned}
& \mathrm{C}-\mathrm{C}_{\mathrm{h}}+1 \leq \mathrm{j} \leq \mathrm{C}-\mathrm{C}_{\mathrm{h}} \\
& \mathrm{C}-\mathrm{C}_{\mathrm{h}}+1<\mathrm{j} \leq \mathrm{C} \\
& \mathrm{C}+1<\mathrm{j} \leq \mathrm{C}+\mathrm{K} \\
& \mathrm{i}=1,2, \ldots \ldots \ldots \ldots . \mathrm{K}
\end{aligned}
$$

Solving this set of difference equations, using generating functions technique, we obtain 


$$
P_{j}= \begin{cases}\frac{1}{j !}\left(\frac{\lambda_{h}+\lambda_{n}}{\mu_{H}}\right)^{j} P_{0,} & 0 \leq j \leq C-C_{h} \\ \frac{1}{j !}\left(\frac{\lambda_{h}+\lambda_{n}}{\mu_{H}}\right)^{C-C_{h}}\left(\frac{\lambda_{h}}{\mu_{H}}\right)^{j-\left(C-C_{h}\right)} P_{0,} & C-C_{h}+1 \leq j \leq C \\ \frac{1}{C !} \frac{\left(\frac{\lambda_{h}+\lambda_{n}}{\mu_{H}}\right)^{C-C_{h}}\left(\frac{\lambda_{h}}{\mu_{H}}\right)^{C h}\left(\lambda_{h d}\right)^{j-C}}{\prod_{i=1}^{K}\left(\mu_{H} C+i \mu_{Q}\right)} P_{0,} & C+1 \leq j \leq C+K\end{cases}
$$

Since $\sum_{\mathrm{j}=0}^{\mathrm{C}+\mathrm{K}} \mathrm{P}_{\mathrm{j}}$ must be unity, i.e. $\sum_{\mathrm{j}=0}^{\mathrm{C}+\mathrm{K}} \mathrm{P}_{\mathrm{j}}=1$

$$
\begin{aligned}
& {\left[\sum_{j=0}^{C-C_{h}} P_{j}+\sum_{j=C-C_{h}+1}^{C} P_{j}+\sum_{j=C+1}^{C+K} P_{j}\right]=1} \\
& {\left[\sum_{j=0}^{C-C_{h}} \frac{1}{j !}\left(\frac{\lambda_{h}+\lambda_{n}}{\mu_{H}}\right)^{j} P_{0}+\sum_{j=C-C}^{C} \frac{1}{j !}\left(\frac{\lambda_{h}+\lambda_{n}}{\mu_{H}}\right)^{C-C}\left(\frac{\lambda_{h}}{\mu_{H}}\right)^{j-\left(C-C_{h}\right)} P_{0}+\sum_{j=C+1}^{C+K} \frac{1}{C !} \frac{\left(\frac{\lambda_{h}+\lambda_{n}}{\mu_{H}}\right)^{C-C h}\left(\frac{\lambda_{h}}{\mu_{H}}\right)^{C_{h}}\left(\lambda_{h d}\right)}{\prod_{i=1}^{K}\left(\mu_{H} C+i \mu_{Q}\right)} P_{0}\right]=1}
\end{aligned}
$$

From above equation we easily obtain $\mathrm{P}_{0}$ as:

$$
P_{0}=\left[\sum_{j=0}^{c-C_{h}} \frac{1}{j !}\left(\frac{\lambda_{h}+\lambda_{n}}{\mu_{H}}\right)^{j}+\sum_{j=C-C C_{h}+j !}^{c} \frac{1}{j !}\left(\frac{\lambda_{h}+\lambda_{n}}{\mu_{H}}\right)^{c-C}\left(\frac{C_{h}}{\mu_{H}}\right)^{j-\left(C-C_{h}\right)}+\sum_{j=C+1}^{C+K} \frac{1}{C !} \frac{\left(\frac{\lambda_{h}+\lambda_{n}}{\mu_{H}}\right)^{C-C_{h}}\left(\frac{\lambda_{h}}{\mu_{H}}\right)^{C_{h}}\left(\lambda_{h d}\right)^{j-C}}{\prod_{i=1}^{K}\left(\mu_{H} C+i \mu_{Q}\right)}\right]^{-1}
$$

The blocking probability of new calls is

$$
P_{B}=\sum_{j=C-C_{h}}^{C+K} P_{j}
$$

The blocking probability of handoff voice is

$$
\mathrm{P}_{\mathrm{Bhv}}=\sum_{\mathrm{j}=\mathrm{C}}^{\mathrm{C}+\mathrm{K}} \mathrm{P}_{\mathrm{j}}
$$

Following Hong and Rappaport ${ }^{[6]}$, the handoff failure probability is expressed as

$$
\mathrm{P}_{\mathrm{fh}}=\mathrm{P}_{\mathrm{C}+\mathrm{K}}+\sum_{\mathrm{k}=0}^{\mathrm{K}-1} \mathrm{P}_{\mathrm{C}+\mathrm{k}} \frac{(\mathrm{k}+1) \mu_{\mathrm{Q}}}{\mathrm{C} \mu_{\mathrm{H}}+(\mathrm{k}+1) \mu_{\mathrm{Q}}}
$$


The probability of force termination is given by

$$
\mathrm{P}_{\mathrm{F}}=\frac{\mathrm{P}_{\mathrm{fh}} \mathrm{P}_{\mathrm{N}}}{1-\mathrm{P}_{\mathrm{H}}\left(1-\mathrm{P}_{\mathrm{fh}}\right)}
$$

where $\mathrm{P}_{\mathrm{N}}$ is the probability that a non-blocked new call will require at least one handoff before completion because of mobile crossing the cell boundary and $\mathrm{P}_{\mathrm{H}}$ is the probability that an already successful hand-off call will require another handoff before completion. These probabilities can be calculated by using the mathematical analysis given by Hong and Rappaport ${ }^{[6]}$.

The probability for non-completion of a call is given by

$$
\mathrm{P}_{\mathrm{nc}}=\mathrm{P}_{\mathrm{B}}+\frac{\mathrm{P}_{\mathrm{fh}} \mathrm{P}_{\mathrm{N}}\left(1-\mathrm{P}_{\mathrm{B}}\right)}{1-\mathrm{P}_{\mathrm{H}}\left(1-\mathrm{P}_{\mathrm{fh}}\right)}
$$

\subsection{Model-II}

In this model we have considered sub-rating of guard channels to give priority to handoff calls, i.e. $\mathrm{C}_{\mathrm{h}}$ channels among the total $\mathrm{C}$ channels are reserved for serving the handoff calls only. When all $C_{h}$ channels are occupied and a handoff call arrives then a full rate channel from reserved channels divided into two half rate channels to accommodate handoff call. Other assumptions are the same as Model-I. Using the state transition diagram, as shown in Fig. 2, we get the steady state probabilities, as given by the following set of difference equations

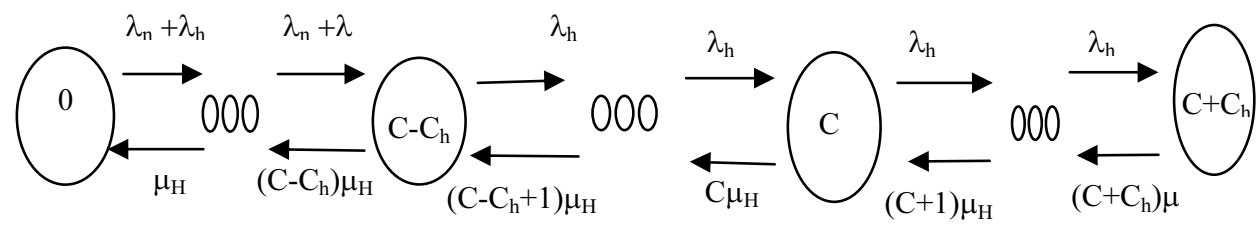

Fig. 2. Transition State Diagram for Model II.

$$
\begin{array}{ll}
P_{j}^{\prime}(t)=-\left(\lambda_{n}+\lambda_{h}\right) P_{P}(t)+\mu_{H} P_{1}(t) & \\
P_{j}^{\prime}(t)=-\left\{\left(\lambda_{n}+\lambda_{h}\right)+j \mu_{H}\right\} P_{j}(t)+\left(\lambda_{n}+\lambda_{h}\right) P_{j-1}(t)+(j+1) \mu_{H} P_{j+1}(t), & 0<j \leq C-C_{h} \\
P_{j}^{\prime}(t)=-\left(\lambda_{h}+j \mu_{H}\right) P_{j}(t)+\lambda_{h} P_{j_{j-1}}(t)+(j+1) \mu_{H} P_{j+1}(t), & C-C_{h}+1 \leq j \leq C+C_{h} \\
P_{j}^{\prime}(t)=-\left\{\lambda_{h d}+\left(\left(C+C_{h}\right) \mu_{H}+i \mu_{Q}\right)\right\} P_{j}(t)+\lambda_{h d} P_{j-1}(t)+\left\{\left(C+C_{h}\right) \mu_{H}+\left(i+1 \mu_{Q}\right)\right\} P_{j+1}, C+C_{h}+1 \leq j \leq C+C_{h}+K & , i=1,2, \ldots \ldots \ldots \ldots ., K
\end{array}
$$

The steady state probabilities for the systems are derived assuming that $P_{j}(t)=P_{j}$, as $t \rightarrow \infty$. The equations for steady state probabilities $P_{j}$, 
for $t \rightarrow \infty$ are obtained by putting $P_{j}^{\prime}(t)=0$ and replacing $P_{j}(t)$ by $P_{j}$ in above equations. Thus, the difference equations become:

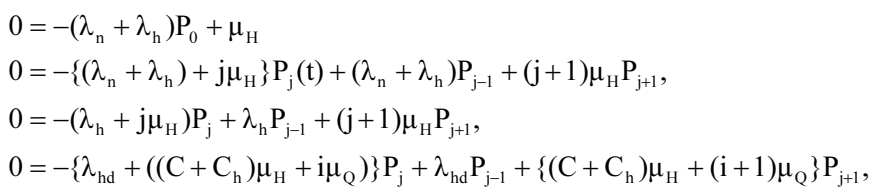
.., K

Solving this set of difference equations, using generating functions technique, we obtain

$$
P_{j}=\left\{\begin{array}{lc}
\frac{1}{j !}\left(\frac{\lambda_{h}+\lambda_{n}}{\mu_{H}}\right)^{j} P_{0}, & 0 \leq j \leq C-C_{h} \\
\frac{1}{j !}\left(\frac{\lambda_{h}+\lambda_{n}}{\mu_{H}}\right)^{C-C_{h}}\left(\frac{\lambda_{h}}{\mu_{H}}\right)^{j-\left(C-C_{h}\right)} P_{0}, & C-C_{h}+1 \leq j \leq C+C_{h} \\
\frac{1}{\left(C+C_{h}\right) !} \frac{\left(\frac{\lambda_{h}+\lambda_{n}}{\mu_{H}}\right)^{\mathrm{C}-\left(C-C_{h}\right.}\left(\frac{\lambda_{h}}{\prod_{i=1}^{2+C}}\right)^{2 C_{h}}\left(\mu_{H}\left(C+C_{h}\right)+i \mu_{Q}\right)}{\left.\mu_{h d}\right)^{j-\left(C+C_{h}\right)}} & C+C_{h}+1 \leq j \leq C+C_{h}+K
\end{array}\right.
$$

Since $\sum_{\mathrm{j}=0}^{\mathrm{C}+\mathrm{C}_{\mathrm{h}}+\mathrm{K}} \mathrm{P}_{\mathrm{j}}=1$, i.e.,

$$
\begin{aligned}
& {\left[\sum_{j=0}^{C-C_{h}} P_{j}+\sum_{j=C-C_{h}+1}^{C+C_{h}} P_{j}+\sum_{j=C+C_{h}+1}^{C+C_{h}+K} P_{j}\right]=1} \\
& {\left[\begin{array}{c}
\sum_{j=0}^{C-C_{h}} \frac{1}{j !}\left(\frac{\lambda_{h}+\lambda_{n}}{\mu_{H}}\right)^{j} P_{0}+\sum_{j=C-C_{h}+1}^{C+C+C_{h}} \frac{1}{j !}\left(\frac{\lambda_{h}+\lambda_{n}}{\mu_{H}}\right)^{C-C_{h}}\left(\frac{\lambda_{h}}{\mu_{H}}\right)^{j-\left(C-C_{h}\right)} P_{0} \\
+\sum_{j=C+C_{h}+1}^{C+C_{h}+K} \frac{1}{\left(C+C_{h}\right) !} \frac{\left(\frac{\lambda_{h}+\lambda_{n}}{\mu_{H}}\right)^{C-C_{h}}\left(\frac{\lambda_{h}}{\mu_{H}}\right)^{2 C_{h}}\left(\lambda_{h d}\right)^{j-\left(C+C_{h}\right)}}{\prod_{i=1}^{j-\left(C+C_{h}\right)}\left(\mu_{H}\left(C+C_{h}\right)+i \mu_{Q}\right)} P_{0}
\end{array}\right]}
\end{aligned}
$$

Then we evaluate value of $\mathrm{P}_{0}$ as: 


$$
P_{0}=\left[\begin{array}{c}
\sum_{j=0}^{C-C_{h}} \frac{1}{j !}\left(\frac{\lambda_{h}+\lambda_{n}}{\mu_{H}}\right)^{j}+\sum_{j=C-C_{h}+1}^{C+C_{h}} \frac{1}{j !}\left(\frac{\lambda_{h}+\lambda_{n}}{\mu_{H}}\right)^{C-C_{h}}\left(\frac{\lambda_{h}}{\mu_{H}}\right)^{j-\left(C-C_{h}\right)} \\
\left.+\sum_{j=C+C_{h}+1}^{C+C+C_{h}+K} \frac{1}{\left(\frac{\lambda_{h}+\lambda_{n}}{\mu_{H}}\right)^{C-C_{h}}\left(\frac{\lambda_{h}}{\mu_{H}}\right)^{2 C_{h}}\left(\lambda_{h d}\right)^{j-\left(C+C_{h}\right)}}\right]_{i=1}^{j-\left(C+C_{h}\right)}\left(\mu_{H}\left(C+C_{h}\right)+i \mu_{Q}\right)
\end{array}\right]
$$

Blocking probability $\mathrm{P}_{\mathrm{B}}$ of new calls, Blocking probability $\mathrm{P}_{\mathrm{Bh}}$ of handoff calls and Probability $\mathrm{P}_{\mathrm{fh}}$ of handoff failure

$$
\begin{aligned}
& P_{B}=\sum_{j=C-C_{h}}^{C+C_{h}+K} P_{j} \\
& P_{B h}=\sum_{j=C+C_{h}}^{C+C_{h}+K} P_{j} \\
& P_{f h}=P_{C+C_{h}+K}+\sum_{k=0}^{C_{h}} P_{C+k}+\sum_{k=C_{h}+1}^{C_{h}+K-1} P_{C+C_{h}+k} \frac{(k+1) \mu_{Q}}{\left(C+C_{h}\right) \mu_{H}+(k+1) \mu_{Q}}
\end{aligned}
$$

The forced termination and call non completion probabilities are same as given in equations (6) and (7). Where $\mathrm{P}_{\mathrm{fh}}$ is given by equation (12).

\subsection{Model-III}

To improve handoff procedure, a multi queue model has been proposed by Louvros et al. ${ }^{[16]}$. There are three different transceivers (TRX) per cell covering the same geographical area and we are working on same idea and based on that we assume that each TRX have a fixed number of channels assigned $\mathrm{C} / 3$, among these channels $\mathrm{C}_{\mathrm{h}} / 3$ channels are assigned exclusively for handoff calls. These guard channels can also be sub-rated to give priority to handoff calls. There are $\mathrm{K} / 3$ positions in each queue. Every new call and handoff call are served randomly by one of the three TRX until all C- $\mathrm{C}_{\mathrm{h}}$ channels are occupied and if all $\mathrm{C}-\mathrm{C}_{\mathrm{h}}$ channels are occupied then reserved channels are assigned to handoff calls only. When all channels are occupied in all three TRX, the reserved channels are sub-rated to serve handoff attempts and if all reserved channel in all queues are sub rated then a handoff voice calls are lost but there is a provision of buffer for handoff data calls.

Hence the blocking probability of a new call $\left(\mathrm{P}_{\mathrm{B}}\right)$ is obtained by taking the product of separate blocking probabilities of any of the three 
TRX given by

$$
\begin{aligned}
P_{B} & =P_{B 1} \cdot P_{B 2} \cdot P_{B 3} \\
& =\sum_{j 1=C-C_{h}}^{C+C_{h}+K} P_{j 2=C-C_{h}}^{C+C} P_{j 2} \sum_{j 3=C-C_{h}}^{C+C_{h}+K} P_{j 3}^{C+C_{h}+K}
\end{aligned}
$$

To find the total handoff failure probability for this model, we have to consider the all possible ways of allocation of handoff attempts in a queue. Since the three transceiver queues are occupied with calls sequentially, then a handoff attempts failure would happen according to the following possible cases:

Case I: If there is no free position for a handoff attempt in any of the three queues and buffer is also occupied then the handoff failure probability is equal to

$$
\mathrm{P}_{\mathrm{I}}=\mathrm{P}_{\mathrm{C}+\mathrm{Ch}+\mathrm{K}, 1} \mathrm{P}_{\mathrm{C}+\mathrm{Ch}+\mathrm{K}, 2} \mathrm{P}_{\mathrm{C}+\mathrm{Ch}+\mathrm{K}, 3} \text {. }
$$

Case II: If all the three queues have the same number of occupied positions (suppose $\mathrm{j}$ ) in queue, so the handoff attempt will enter position $\mathrm{j}+1$ in one of the three queues with equal probability, then the handoff failure probability is

$$
P_{I I}=3 P_{C+C h+j, 1} P_{C+C h+j, 2} P_{C+C h+j, 3} \frac{(j+1) \mu_{Q}}{\left(C+C_{h}\right) \mu_{H}+(j+1) \mu_{Q}}
$$

Case III: If two transceivers having $\mathrm{j}$ occupied position and other one have $(j+1)$ occupied position, then the handoff failure probability is

$$
\mathrm{P}_{\mathrm{III}}=2 * 3 \mathrm{P}_{\mathrm{C}+\mathrm{Ch}+\mathrm{j}+1,1} \mathrm{P}_{\mathrm{C}+\mathrm{Ch}+\mathrm{j}, 2} \mathrm{P}_{\mathrm{C}+\mathrm{Ch}+\mathrm{j}, 3} \frac{(\mathrm{j}+1) \mu_{\mathrm{Q}}}{\left(\mathrm{C}+\mathrm{C}_{\mathrm{h}}\right) \mu_{\mathrm{H}}+(\mathrm{j}+1) \mu_{\mathrm{Q}}}
$$

Case IV: If two transceivers having $(j+1)$ occupied position an other one have $\mathrm{j}$ position. Thus the handoff failure probability is given by

$$
P_{I V}=3 P_{C+C h+j+1,1} P_{C+C h+j+1,2} P_{C+C h+j, 3} \frac{(j+1) \mu_{Q}}{\left(C+C_{h}\right) \mu_{H}+(j+1) \mu_{Q}}
$$

Now we can combine the above cases to find the handoff failure probability for model III.

$$
\begin{aligned}
\mathrm{P}_{\mathrm{fh}}=\mathrm{P}_{\mathrm{I}}+\sum_{\mathrm{j}=0}^{\mathrm{K}-1}\left(\mathrm{P}_{\mathrm{II}}+\mathrm{P}_{\mathrm{III}}+\mathrm{P}_{\mathrm{IV}}\right) & \\
= & \mathrm{P}_{\mathrm{C}+\mathrm{Ch}+\mathrm{K}, 1} \mathrm{P}_{\mathrm{C}+\mathrm{Ch}+\mathrm{K}, 2} \mathrm{P}_{\mathrm{C}+\mathrm{Ch}+\mathrm{K}, 3}
\end{aligned}
$$




$$
+3 \sum_{j=0}^{K-1}\left[\begin{array}{c}
P_{C+C_{h}+j, 1} P_{C+C_{h}+j, 2} P_{C+C_{h}+j, 3} \frac{(j+1) \mu_{Q}}{\left(C+C_{h}\right) \mu_{H}+(j+1) \mu_{Q}} \\
+2 P_{C+C_{h}+j+1,1} P_{C+C_{h}+j, 2} P_{C+C_{h}+j, 3} \frac{(j+1) \mu_{Q}}{\left(C+C_{h}\right) \mu_{H}+(j+1) \mu_{Q}} \\
+P_{C+C_{h}+j+1,1} P_{C+C_{h}+j+1,2} P_{C+C_{h}+j, 3} \frac{(j+1) \mu_{Q}}{\left(C+C_{h}\right) \mu_{H}+(j+1) \mu_{Q}}
\end{array}\right]
$$

The force termination probability is

$$
\mathrm{P}_{\mathrm{F}}=\frac{\mathrm{P}_{\mathrm{fh}} \mathrm{P}_{\mathrm{N}}}{1-\mathrm{P}_{\mathrm{H}}\left(1-\mathrm{P}_{\mathrm{fh}}\right)}
$$

The non-completion probability

$$
\mathrm{P}_{\mathrm{nc}}=\mathrm{P}_{\mathrm{B}}+\frac{\mathrm{P}_{\mathrm{fh}} \mathrm{P}_{\mathrm{N}}\left(1-\mathrm{P}_{\mathrm{B}}\right)}{1-\mathrm{P}_{\mathrm{H}}\left(1-\mathrm{P}_{\mathrm{fh}}\right)}
$$

Where $\mathrm{P}_{\mathrm{fh}}$ is given by equation (13).

\section{Numerical Results}

To check the validity of the models described in previous section we performed numerical evaluation and computed the blocking probabilities and other performance measures. For this purpose we have taken 21 channels in the cell, out of these three are reserved for handoff calls $\left(\mathrm{C}_{\mathrm{h}}=3\right)$ per cell. In the model III, we consider three TRX queues per cell, we have considered that each transceiver has a total of seven channels $(C=7)$ out of these seven channels one channel is reserved for handoff calls $\left(C_{h}=1\right)$. We have used software MATLAB to develop computational program, after programming in MATLAB, the data is obtained from MATLAB, performing simulation of these data we carried out the numerical work. As far as the values of various parameters are concerned, we have taken relative values of the parameters as contained in Ref. [8].

In order to compare the effect of various parameters on blocking probability, handoff failure probability, force termination probability, probability of non-completion of a call, we have considered different values of these parameters. In order to calculate the probability $\mathrm{P}_{\mathrm{nc}}$ of 
non-completion of a call, we require to calculate the probability $\mathrm{P}_{\mathrm{N}}$ of a completed new call and probability $\mathrm{P}_{\mathrm{N}}$ of a completed handed off call. By using the procedure given in ${ }^{[6]}$ the values of these probabilities are $\mathrm{P}_{\mathrm{N}}=$ $0.4364540, \mathrm{P}_{\mathrm{H}}=0.3162866$. We consider the following four cases:

CASE I: $\mathrm{K}=3$ in model $\mathrm{I}$ and for $\mathrm{K}=1$ in model II and III (since we are using sub rating), Even for these values of $\mathrm{K}$ we consider the different cases

Case (i) $\mathrm{K}=3, \mu_{\mathrm{H}}=0.01, \mu_{\mathrm{Q}}=0.005, \lambda_{\mathrm{nv}}=0.3, \lambda_{\mathrm{nd}}=0.2, \mathrm{P}_{\mathrm{N}}=$ $0.4364540, \mathrm{P}_{\mathrm{H}}=0.3162866$.

Case (ii) $\mathrm{K}=3, \mu_{\mathrm{H}}=0.025, \mu_{\mathrm{Q}}=0.015, \lambda_{\mathrm{nv}}=0.3, \lambda_{\mathrm{nd}}=0.2, \mathrm{P}_{\mathrm{N}}=$ $0.4364540, \mathrm{P}_{\mathrm{H}}=0.3162866$.

CASE II: $\mathrm{K}=6, \mu_{\mathrm{H}}=0.019, \mu_{\mathrm{Q}}=0.01, \lambda_{\mathrm{nv}}=0.3, \lambda_{\text {nd }}=0.2, \mathrm{P}_{\mathrm{N}}=$ $0.4364540, \mathrm{P}_{\mathrm{H}}=0.3162866$.

CASE III: $\mathrm{K}=9$, for model $\mathrm{I}$ and $\mathrm{K}=3$ for model II, III, There are two sub cases

Case (i) $\mathrm{K}=9, \mu_{\mathrm{H}}=0.01, \mu_{\mathrm{Q}}=0.005, \lambda_{\mathrm{nv}}=0.3, \lambda_{\mathrm{nd}}=0.2, \mathrm{P}_{\mathrm{N}}=$ $0.4364540, \mathrm{P}_{\mathrm{H}}=0.3162866$

Case (ii) $\mathrm{K}=9, \mu_{\mathrm{H}}=0.025, \mu_{\mathrm{Q}}=0.015, \lambda_{\mathrm{nv}}=0.3, \lambda_{\mathrm{nd}}=0.2, \mathrm{P}_{\mathrm{N}}=$ $0.4364540, \mathrm{P}_{\mathrm{H}}=0.3162866$

CASE IV: When $\mathrm{K}=12$ for model $\mathrm{I}$ and $\mathrm{K}=4$ for model II, III, There are two sub cases

Case (i) $\mathrm{K}=12, \mu_{\mathrm{H}}=0.01, \mu_{\mathrm{Q}}=0.005, \lambda_{\mathrm{nv}}=0.3, \lambda_{\text {nd }}=0.2, \mathrm{P}_{\mathrm{N}}=$ $0.4364540, \mathrm{P}_{\mathrm{H}}=0.3162866$

Case (ii) $\mathrm{K}=12, \mu_{\mathrm{H}}=0.025, \mu_{\mathrm{Q}}=0.015, \lambda_{\mathrm{nv}}=0.3, \lambda_{\mathrm{nd}}=0.2, \mathrm{P}_{\mathrm{N}}=$ $0.4364540, \mathrm{P}_{\mathrm{H}}=0.3162866$

CASE I: Figure 3 shows the effect of arrival rate of new data calls $\left(\lambda_{\text {nd }}\right)$ on blocking probability of new call $\left(\mathrm{P}_{\mathrm{B}}\right)$ for all three models. The blocking probability of model III is higher than other two models, which is due to priority given to handoff calls at the cost of new calls, Fig. 4 and 5 present the effect of $\lambda_{\text {nd }}$ on $\mathrm{P}_{\text {fh }}$ and $\mathrm{P}_{\mathrm{F}}$ respectively; we observe that the $\mathrm{P}_{\text {fh }}$ 
and $\mathrm{P}_{\mathrm{F}}$ of model III is much less than other two models, Fig. 6 depicts the Non-completion probabilities of model III which is higher compared to other two models. Figures 7 and 8 show the effect of arrival rate of new voice calls $\left(\lambda_{n v}\right)$ on $\mathrm{P}_{\mathrm{B}}$ and $\mathrm{P}_{\mathrm{fh}}$ for all three models respectively. In this case the $\mathrm{P}_{\mathrm{B}}$ for model III is higher than the other two models and $\mathrm{P}_{\mathrm{fh}}$ for model II and III are much less than model I, Fig. 9 and 10 present the effect of $\lambda_{\text {nv }}$ on $\mathrm{P}_{\mathrm{F}}$ and $\mathrm{P}_{\mathrm{nc}}$ respectively, it is observed that $\mathrm{P}_{\mathrm{F}}$ of model I and III are much less than model II, and $\mathrm{P}_{\mathrm{nc}}$ of model II is higher than other two models and $\mathrm{P}_{\mathrm{nc}}$ of model III lies between model I and II.

The calculated values of these parameters, whose figures are drawn above, are included in Appendix I.

Case (ii): In order to reduce the size of main paper, we have not drawn figures for this sub case; however, we have included the obtained data in Appendix II.

CASE II: $K=6, \mu_{\mathrm{H}}=0.019, \mu_{\mathrm{Q}}=0.01, \lambda_{\mathrm{nv}}=0.3, \lambda_{\mathrm{nd}}=0.2, \mathrm{P}_{\mathrm{N}}=$ $0.4364540, \mathrm{P}_{\mathrm{H}}=0.3162866$. Figure 11 shows the effect of arrival rate of new voice calls $\left(\lambda_{\text {nv }}\right)$ on blocking probability of new call $\left(\mathrm{P}_{\mathrm{B}}\right)$ for all three models. The blocking probability of model III is higher than other two models, which is obvious because we are giving priority to handoff calls at the cost of new calls. Figure 12 illustrates that the handoff failure probability $\left(\mathrm{P}_{\mathrm{fh}}\right)$ of model III increases with the increase in arrival rate of new voice calls $\left(\lambda_{\text {nv }}\right)$ but the lowest among three models. The data are given in the Tables 1 and 2 .

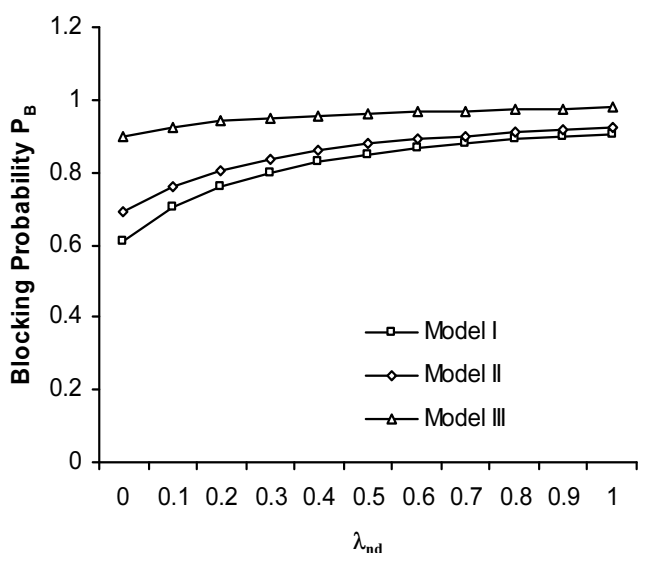

Fig. 3. Blocking probability of new calls vs. arrival rate of new data calls. 


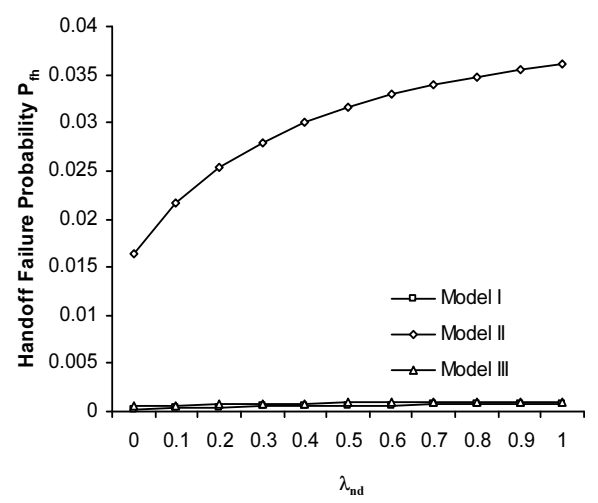

Fig. 4. Handoff failure probability vs. arrival rate of new data calls.

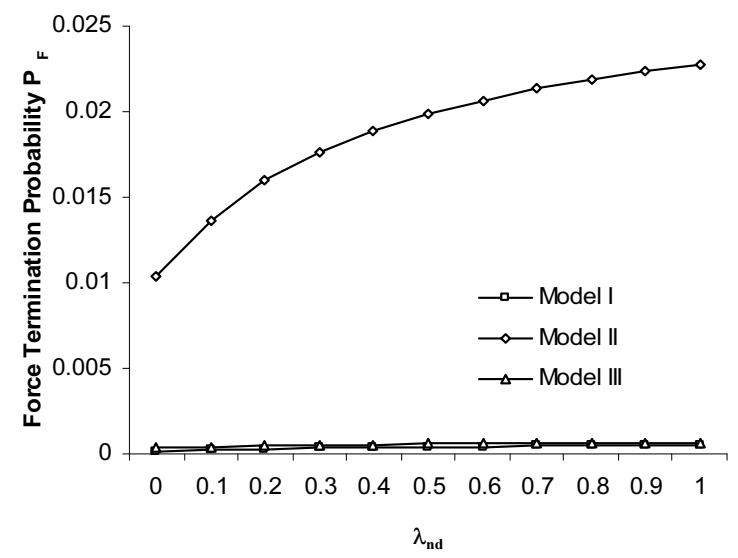

Fig. 5. Force termination probability $v s$. arrival rate of new data calls.

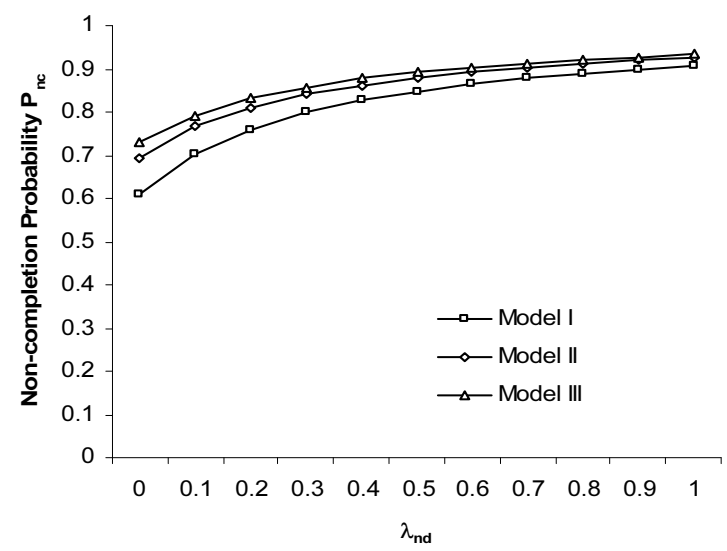

Fig. 6. Probability of not completed calls vs. arrival rate of new data calls. 


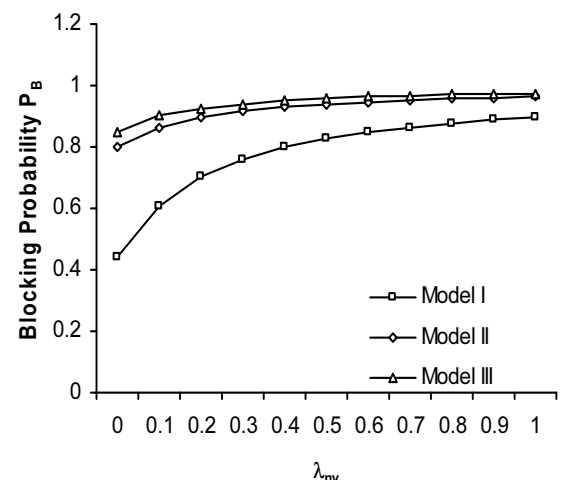

Fig. 7. Blocking probability of new calls vs. arrival rate of new voice calls.

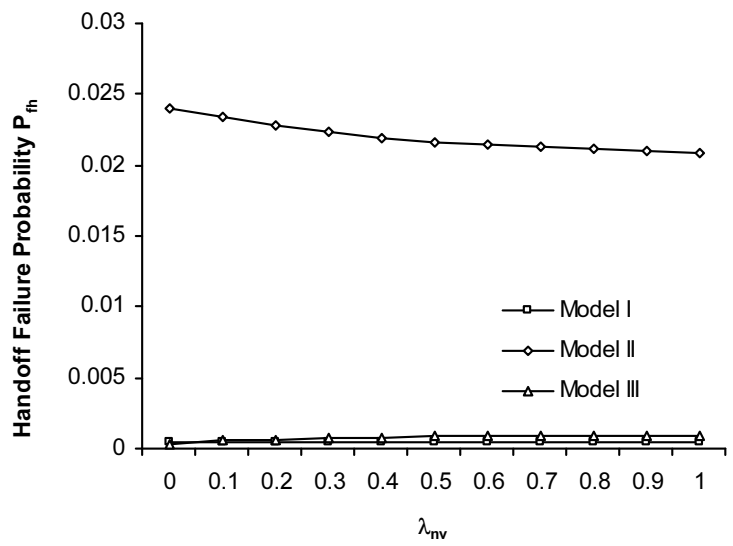

Fig. 8. Handoff failure probability vs. arrival rate of new voice calls.

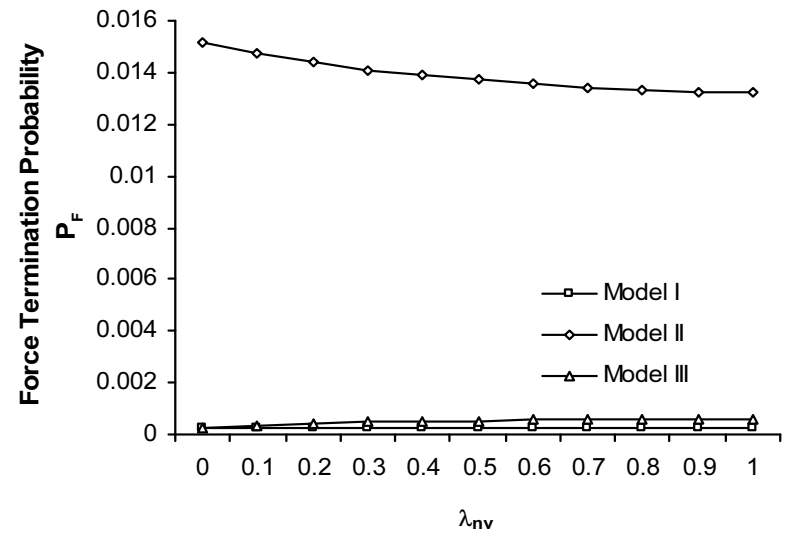

Fig. 9. Force termination probability vs. arrival rate of new voice calls. 


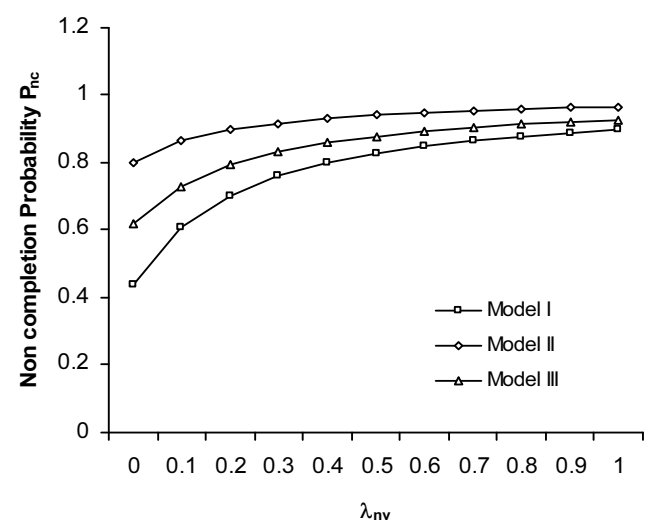

Fig. 10. Probability of not completed calls vs. arrival rate of new voice calls.

Table 1.

\begin{tabular}{|l|l|l|l|}
\hline & $\begin{array}{c}\text { Model I } \\
\left(\mathrm{P}_{\mathrm{fh}}\right)\end{array}$ & $\begin{array}{c}\text { Model II } \\
\left(\mathrm{P}_{\mathrm{fh}}\right)\end{array}$ & \multicolumn{1}{|c|}{$\begin{array}{c}\text { Model III } \\
\left(\mathrm{P}_{\mathrm{fh}}\right)\end{array}$} \\
\hline$\lambda_{\mathrm{nv}}=0.0$ & $5.3 \mathrm{E}-05$ & 0.00048 & $1.26 \mathrm{E}-08$ \\
\hline$\lambda_{\mathrm{nv}}=0.1$ & 0.00018 & 0.00063 & $6.66 \mathrm{E}-08$ \\
\hline$\lambda_{\mathrm{nv}}=0.2$ & 0.000271 & 0.00072 & $1.454 \mathrm{E}-07$ \\
\hline$\lambda_{\mathrm{nv}}=0.3$ & 0.000329 & 0.00078 & $2.274 \mathrm{E}-07$ \\
\hline$\lambda_{\mathrm{nv}}=0.4$ & 0.000368 & 0.00082 & $3.035 \mathrm{E}-07$ \\
\hline$\lambda_{\mathrm{nv}}=0.5$ & 0.000395 & 0.00085 & $3.714 \mathrm{E}-07$ \\
\hline$\lambda_{\mathrm{nv}}=0.6$ & 0.000416 & 0.00087 & $4.309 \mathrm{E}-07$ \\
\hline$\lambda_{\mathrm{nv}}=0.7$ & 0.000431 & 0.00088 & $4.83 \mathrm{E}-07$ \\
\hline$\lambda_{\mathrm{nv}}=0.8$ & 0.000443 & 0.00090 & $5.287 \mathrm{E}-07$ \\
\hline$\lambda_{\mathrm{nv}}=0.9$ & 0.000453 & 0.00091 & $5.686 \mathrm{E}-07$ \\
\hline$\lambda_{\mathrm{nv}}=1.0$ & 0.000461 & 0.00092 & $6.044 \mathrm{E}-07$ \\
\hline
\end{tabular}

Table 2.

\begin{tabular}{|l|l|l|l|}
\hline & $\begin{array}{c}\text { Model I } \\
\left(\mathrm{P}_{\mathrm{B}}\right)\end{array}$ & $\begin{array}{c}\text { Model II } \\
\left(\mathrm{P}_{\mathrm{B}}\right)\end{array}$ & $\begin{array}{c}\text { Model III } \\
\left(\mathrm{P}_{\mathrm{B}}\right)\end{array}$ \\
\hline$\lambda_{\mathrm{nv}}=0.0$ & 0.12386 & 0.52870 & 0.55573 \\
\hline$\lambda_{\mathrm{nv}}=0.1$ & 0.32724 & 0.66759 & 0.69409 \\
\hline$\lambda_{\mathrm{nv}}=0.2$ & 0.46968 & 0.74457 & 0.76794 \\
\hline$\lambda_{\mathrm{nv}}=0.3$ & 0.56546 & 0.79287 & 0.81334 \\
\hline$\lambda_{\mathrm{nv}}=0.4$ & 0.63286 & 0.82583 & 0.84397 \\
\hline$\lambda_{\mathrm{nv}}=0.5$ & 0.68249 & 0.84982 & 0.86599 \\
\hline$\lambda_{\mathrm{nv}}=0.6$ & 0.72046 & 0.86803 & 0.88259 \\
\hline$\lambda_{\mathrm{nv}}=0.7$ & 0.75038 & 0.88230 & 0.89553 \\
\hline$\lambda_{\mathrm{nv}}=0.8$ & 0.77456 & 0.89381 & 0.90591 \\
\hline$\lambda_{\mathrm{nv}}=0.9$ & 0.79449 & 0.90326 & 0.91441 \\
\hline$\lambda_{\mathrm{nv}}=1.0$ & 0.81119 & 0.91117 & 0.92151 \\
\hline
\end{tabular}




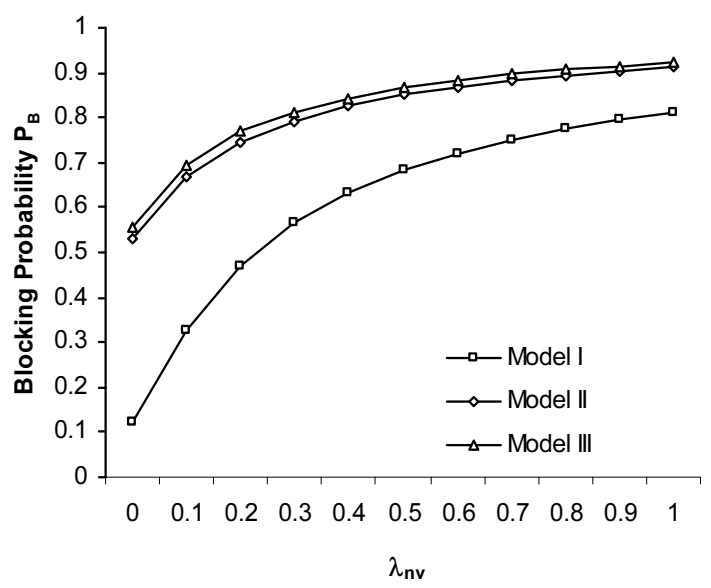

Fig. 11. Blocking probability of new calls vs. arrival rate of new voice calls.

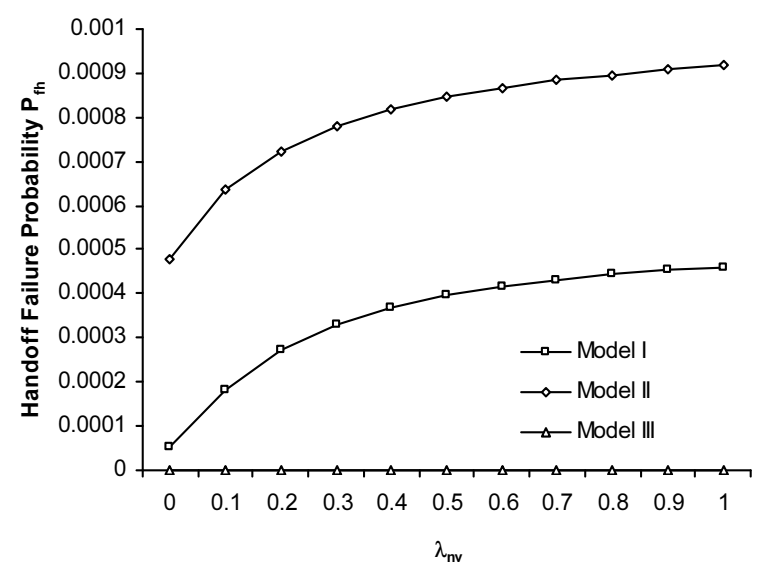

Fig. 12. Handoff failure probability $v s$. arrival rate of new voice calls.

Figure 13 depicts the force termination probabilities $\left(\mathrm{P}_{\mathrm{F}}\right)$ of model III is lesser than other two models but $\mathrm{P}_{\mathrm{F}}$ increases with the increase in $\lambda_{\mathrm{nv}}$. Figure 14 shows the effect of arrival rate of new voice calls on $\mathrm{P}_{\mathrm{nc}}$ and we note from that model I is better than model III for low arrival rate of new voice calls $\left(\lambda_{\text {nv }}\right)$ (in between 0 to 0.1 ) but for higher values of $\lambda_{\text {nv }}$ (in between 0.1 to 1 ) model III is better than other models. The data for these figures are given in Tables 3 and 4. 
Table 3.

\begin{tabular}{|l|c|c|c|}
\hline & $\begin{array}{c}\text { Model I } \\
\left(P_{\mathrm{F}}\right)\end{array}$ & $\begin{array}{c}\text { Model II } \\
\left(\mathrm{P}_{\mathrm{F}}\right)\end{array}$ & $\begin{array}{c}\text { Model III } \\
\left(\mathrm{P}_{\mathrm{F}}\right)\end{array}$ \\
\hline$\lambda_{\mathrm{nv}}=0.0$ & 0.000033 & 0.000306 & $8 \mathrm{E}-09$ \\
\hline$\lambda_{\mathrm{nv}}=0.1$ & 0.000115 & 0.000405 & $4.25 \mathrm{E}-08$ \\
\hline$\lambda_{\mathrm{nv}}=0.2$ & 0.000173 & 0.000461 & $9.28 \mathrm{E}-08$ \\
\hline$\lambda_{\mathrm{nv}}=0.3$ & 0.000210 & 0.000497 & $1.45 \mathrm{E}-07$ \\
\hline$\lambda_{\mathrm{nv}}=0.4$ & 0.000235 & 0.000521 & $1.94 \mathrm{E}-07$ \\
\hline$\lambda_{\mathrm{nv}}=0.5$ & 0.000252 & 0.000539 & $2.37 \mathrm{E}-07$ \\
\hline$\lambda_{\mathrm{nv}}=0.6$ & 0.000265 & 0.000553 & $2.75 \mathrm{E}-07$ \\
\hline$\lambda_{\mathrm{nv}}=0.7$ & 0.000275 & 0.000564 & $3.08 \mathrm{E}-07$ \\
\hline$\lambda_{\mathrm{nv}}=0.8$ & 0.000282 & 0.000572 & $3.38 \mathrm{E}-07$ \\
\hline$\lambda_{\mathrm{nv}}=0.9$ & 0.000289 & 0.000579 & $3.63 \mathrm{E}-07$ \\
\hline$\lambda_{\mathrm{nv}}=1.0$ & 0.000294 & 0.000585 & $3.86 \mathrm{E}-07$ \\
\hline
\end{tabular}

Figure 15 displays that the blocking probability of new calls $\left(\mathrm{P}_{\mathrm{B}}\right)$ increases with increases arrival rate of new data calls $\left(\lambda_{\text {nd }}\right)$ but blocking probability of new calls $\left(\mathrm{P}_{\mathrm{B}}\right)$ for model III is higher as compared to other two models, which is due to priority given to handoff calls at the cost of new calls. Figure 16 present the effect of $\lambda_{n d}$ on $\mathrm{P}_{\mathrm{fh}}$ and $\mathrm{P}_{\mathrm{F}}$ respectively, from these figures we find that the $\mathrm{P}_{\mathrm{fh}}$ and $\mathrm{P}_{\mathrm{F}}$ of model III is much lesser than other two models. The data for these figures are given in Tables 5 and 6.

Table 4.

\begin{tabular}{|l|l|l|l|}
\hline & $\begin{array}{c}\text { Model I } \\
\left(\mathrm{P}_{\mathrm{nc}}\right)\end{array}$ & $\begin{array}{c}\text { Model II } \\
\left(\mathrm{P}_{\mathrm{nc}}\right)\end{array}$ & $\begin{array}{c}\text { Model III } \\
\left(\mathrm{P}_{\mathrm{nc}}\right)\end{array}$ \\
\hline$\lambda_{\mathrm{nv}}=0.0$ & 0.123894 & 0.528844 & 0.17163 \\
\hline$\lambda_{\mathrm{nv}}=0.1$ & 0.32732 & 0.667725 & 0.334389 \\
\hline$\lambda_{\text {nv }}=0.2$ & 0.469773 & 0.744595 & 0.452878 \\
\hline$\lambda_{\mathrm{nv}}=0.3$ & 0.565555 & 0.792883 & 0.538038 \\
\hline$\lambda_{\text {nv }}=0.4$ & 0.632943 & 0.825917 & 0.601138 \\
\hline$\lambda_{\mathrm{nv}}=0.5$ & 0.682574 & 0.849906 & 0.649446 \\
\hline$\lambda_{\mathrm{nv}}=0.6$ & 0.720531 & 0.868103 & 0.687497 \\
\hline$\lambda_{\mathrm{nv}}=0.7$ & 0.750452 & 0.882376 & 0.718192 \\
\hline$\lambda_{\mathrm{nv}}=0.8$ & 0.774625 & 0.893867 & 0.74345 \\
\hline$\lambda_{\mathrm{nv}}=0.9$ & 0.794551 & 0.903316 & 0.764586 \\
\hline$\lambda_{\mathrm{nv}}=1.0$ & 0.811254 & 0.911222 & 0.782526 \\
\hline
\end{tabular}




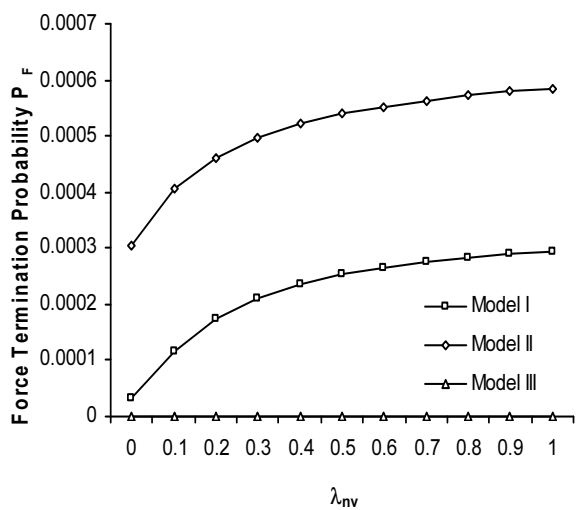

Fig. 13. Force termination probability $v$ s. arrival rate of new voice calls.

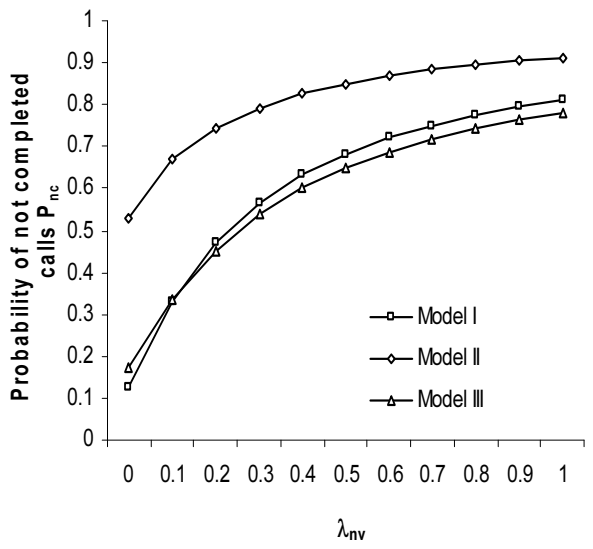

Fig. 14. Probability of not completed calls vs. arrival rate of new voice calls.

Table 5.

\begin{tabular}{|l|l|l|l|}
\hline & $\begin{array}{c}\text { Model I } \\
\left(\mathrm{P}_{\text {fh }}\right)\end{array}$ & $\begin{array}{c}\text { Model II } \\
\left(\mathrm{P}_{\text {fh }}\right)\end{array}$ & \multicolumn{1}{|c|}{$\begin{array}{c}\text { Model III } \\
\left(\mathrm{P}_{\text {fh }}\right)\end{array}$} \\
\hline$\lambda_{\text {nd }}=0.0$ & 0.000125 & 0.000626 & $5.7 \mathrm{E}-08$ \\
\hline$\lambda_{\text {nd }}=0.1$ & 0.000235 & 0.000718 & $1.37 \mathrm{E}-07$ \\
\hline$\lambda_{\text {nd }}=0.2$ & 0.000329 & 0.000779 & $2.27 \mathrm{E}-07$ \\
\hline$\lambda_{\text {nd }}=0.3$ & 0.000407 & 0.000821 & $3.17 \mathrm{E}=07$ \\
\hline$\lambda_{\text {nd }}=0.4$ & 0.000471 & 0.000852 & $4.01 \mathrm{E}-07$ \\
\hline$\lambda_{\text {nd }}=0.5$ & 0.000524 & 0.000876 & $4.78 \mathrm{E}-07$ \\
\hline$\lambda_{\text {nd }}=0.6$ & 0.000568 & 0.000895 & $5.76 \mathrm{E}-07$ \\
\hline$\lambda_{\text {nd }}=0.7$ & 0.000606 & 0.00091 & $6.08 \mathrm{E}-07$ \\
\hline$\lambda_{\text {nd }}=0.8$ & 0.000638 & 0.000923 & $6.63 \mathrm{E}-07$ \\
\hline$\lambda_{\text {nd }}=0.9$ & 0.000666 & 0.000934 & $7.13 \mathrm{E}-07$ \\
\hline$\lambda_{\text {nd }}=1.0$ & 0.00069 & 0.000943 & $7.57 \mathrm{E}-07$ \\
\hline
\end{tabular}


Table 6.

\begin{tabular}{|l|l|l|l|}
\hline & \multicolumn{1}{|c|}{$\begin{array}{c}\text { Model I } \\
\left(\mathrm{P}_{\mathrm{B}}\right)\end{array}$} & $\begin{array}{c}\text { Model II } \\
\left(\mathrm{P}_{\mathrm{B}}\right)\end{array}$ & \multicolumn{1}{c|}{$\begin{array}{c}\text { Model III } \\
\left(\mathrm{P}_{\mathrm{B}}\right)\end{array}$} \\
\hline$\lambda_{\text {nd }}=0.0$ & 0.326725 & 0.667552 & 0.693838 \\
\hline$\lambda_{\text {nd }}=0.1$ & 0.469421 & 0.744464 & 0.767838 \\
\hline$\lambda_{\text {nd }}=0.2$ & 0.565463 & 0.79278 & 0.813338 \\
\hline$\lambda_{\text {nd }}=0.3$ & 0.633044 & 0.825834 & 0.844028 \\
\hline$\lambda_{\text {nd }}=0.4$ & 0.682805 & 0.849836 & 0.866093 \\
\hline$\lambda_{\text {nd }}=0.5$ & 0.720848 & 0.868044 & 0.882709 \\
\hline$\lambda_{\text {nd }}=0.6$ & 0.750824 & 0.882324 & 0.895667 \\
\hline$\lambda_{\text {nd }}=0.7$ & 0.775031 & 0.893821 & 0.906052 \\
\hline$\lambda_{\text {nd }}=0.8$ & 0.794977 & 0.903275 & 0.91456 \\
\hline$\lambda_{\text {nd }}=0.9$ & 0.811691 & 0.911185 & 0.921658 \\
\hline$\lambda_{\text {nd }}=1.0$ & 0.825895 & 0.917901 & 0.927668 \\
\hline
\end{tabular}

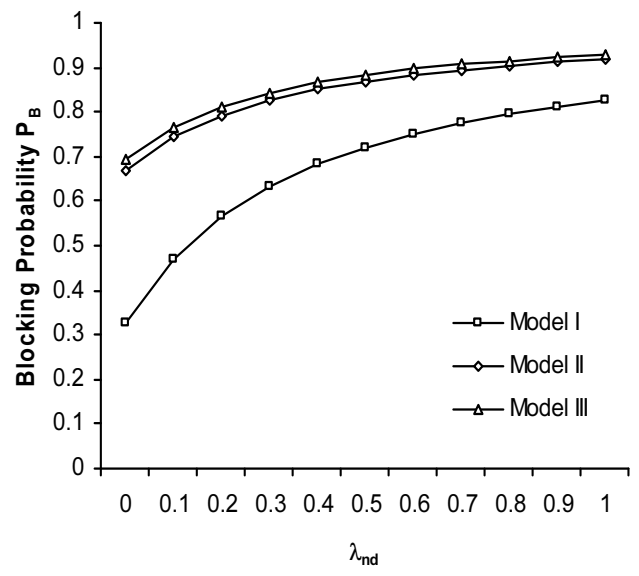

Fig. 15. Blocking probability of new calls $v s$. arrival rate of new data calls.

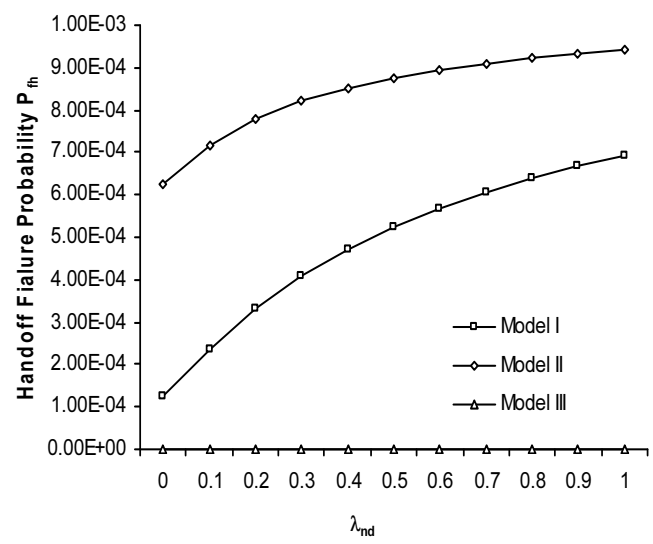

Fig. 16. Handoff failure probability vs. arrival rate of new data calls. 
Figure 17 present the effect of $\lambda_{\text {nd }}$ on $\mathrm{P}_{\mathrm{fh}}$ and $\mathrm{P}_{\mathrm{F}}$ respectively, from these figures we find that the $\mathrm{P}_{\mathrm{fh}}$ and $\mathrm{P}_{\mathrm{F}}$ of model III is much lesser than other two models. In Fig. 18 the $\mathrm{P}_{\mathrm{nc}}$ with $\lambda_{\text {nd }}$ are plotted for all three models. As we notice that $\mathrm{P}_{\mathrm{nc}}$ for model III and I are closer for lesser values of $\lambda_{\text {nd }}$ but as the $\lambda_{\text {nd }}$ increases the difference in $\mathrm{P}_{\mathrm{nc}}$ of both models is clear. So we can say that again the model III is having slightly less $\mathrm{P}_{\mathrm{nc}}$ than model II. The data for these figures are given in Tables 7 and 8 .

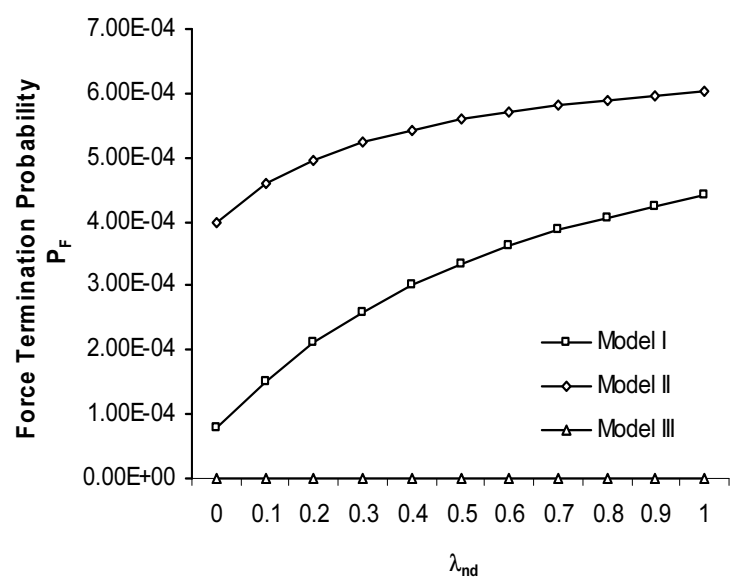

Fig. 17. Force termination probability vs. arrival rate of new data calls.

Table 7.

\begin{tabular}{|l|l|c|c|}
\hline & $\begin{array}{c}\text { Model I } \\
\left(\mathrm{P}_{\mathrm{F}}\right)\end{array}$ & $\begin{array}{c}\text { Model II } \\
\left(\mathrm{P}_{\mathrm{F}}\right)\end{array}$ & $\begin{array}{c}\text { Model III } \\
\left(\mathrm{P}_{\mathrm{F}}\right)\end{array}$ \\
\hline$\lambda_{\mathrm{nd}}=0.0$ & 0.000080 & 0.000399 & $3.64 \mathrm{E}-08$ \\
\hline$\lambda_{\mathrm{nd}}=0.1$ & 0.00015 & 0.000458 & $8.72 \mathrm{E}-08$ \\
\hline$\lambda_{\mathrm{nd}}=0.2$ & 0.00021 & 0.000497 & $1.45 \mathrm{E}-07$ \\
\hline$\lambda_{\mathrm{nd}}=0.3$ & 0.00026 & 0.000524 & $2.03 \mathrm{E}-07$ \\
\hline$\lambda_{\mathrm{nd}}=0.4$ & 0.000301 & 0.000544 & $2.56 \mathrm{E}-07$ \\
\hline$\lambda_{\mathrm{nd}}=0.5$ & 0.000334 & 0.000559 & $3.05 \mathrm{E}-07$ \\
\hline$\lambda_{\mathrm{nd}}=0.6$ & 0.000363 & 0.000571 & $3.49 \mathrm{E}-07$ \\
\hline$\lambda_{\mathrm{nd}}=0.7$ & 0.000387 & 0.000581 & $3.88 \mathrm{E}-07$ \\
\hline$\lambda_{\mathrm{nd}}=0.8$ & 0.000407 & 0.000589 & $4.23 \mathrm{E}-07$ \\
\hline$\lambda_{\mathrm{nd}}=0.9$ & 0.000425 & 0.000596 & $4.55 \mathrm{E}-07$ \\
\hline$\lambda_{\mathrm{nd}}=1.0$ & 0.000441 & 0.000602 & $4.83 \mathrm{E}-07$ \\
\hline
\end{tabular}


Table 8.

\begin{tabular}{|l|l|l|l|}
\hline & $\begin{array}{c}\text { Model I } \\
\left(\mathrm{P}_{\text {nc }}\right)\end{array}$ & $\begin{array}{c}\text { Model II } \\
\left(\mathrm{P}_{\text {nc }}\right)\end{array}$ & $\begin{array}{c}\text { Model III } \\
\left(\mathrm{P}_{\text {nc }}\right)\end{array}$ \\
\hline$\lambda_{\text {nd }}=0.0$ & 0.326778 & 0.667685 & 0.334021 \\
\hline$\lambda_{\text {nd }}=0.1$ & 0.469500 & 0.744581 & 0.452699 \\
\hline$\lambda_{\text {nd }}=0.2$ & 0.565555 & 0.792883 & 0.538038 \\
\hline$\lambda_{\text {nd }}=0.3$ & 0.633140 & 0.825925 & 0.601271 \\
\hline$\lambda_{\text {nd }}=0.4$ & 0.682900 & 0.849917 & 0.649672 \\
\hline$\lambda_{\text {nd }}=0.5$ & 0.720941 & 0.868117 & 0.687785 \\
\hline$\lambda_{\text {nd }}=0.6$ & 0.750914 & 0.882391 & 0.718521 \\
\hline$\lambda_{\text {nd }}=0.7$ & 0.775118 & 0.893883 & 0.743806 \\
\hline$\lambda_{\text {nd }}=0.8$ & 0.795061 & 0.903332 & 0.764957 \\
\hline$\lambda_{\text {nd }}=0.9$ & 0.811771 & 0.911238 & 0.782905 \\
\hline$\lambda_{\text {nd }}=1.0$ & 0.825971 & 0.91795 & 0.798321 \\
\hline
\end{tabular}

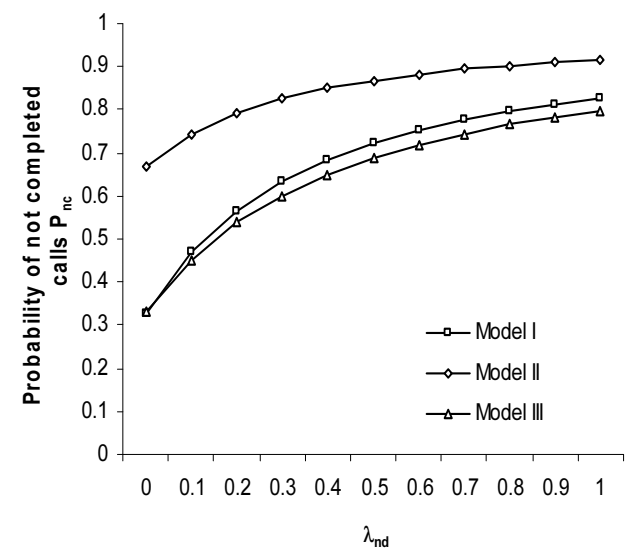

Fig. 18. Probability of not completed calls vs. arrival rate of new data calls.

From the numerical illustrations it is clear that the model III is better than model II or model I in predicting the performance of Cellular Networks, when the traffic (i.e. arrival rate) is high.

Case III: We assume $\mathrm{K}=9$, for model I and $\mathrm{K}=3$ for model II, III. In order to reduce the size of main paper, we have not drawn figures for this case; however, we have included the obtained data in Appendix III and IV respectively.

Case IV: When $\mathrm{K}=12$ for model $\mathrm{I}$ and $\mathrm{K}=4$ for model II, III, we have not drawn figures for this case also, however, the data for these two sub cases are given in Appendix V and VI respectively. 
Looking all these cases we conclude that, when $\mathrm{K}$ increases then the blocking probabilities increase, handoff failure probabilities decrease, forced termination probability decreases, non completion probability of a call is increased.

\section{Conclusion}

Three traffic models for cellular networks have been considered. The first model is classical model, and in the second model we considered the sub-rating to give more channels to handoff calls and in the third model we proposed the three dedicated queue at each transceiver. Sub-rating is allowed to give priority to handoff calls. Finite size of buffer is provided in all models to give high priority to handoff data calls over handoff voice calls. The computed numerical results reveal that the model-III gives the better results in term of less forced termination probability and call non-completion probability but at the same time the blocking of new call increases. We conclude that the model-III gives better quality of service (QOS) for handoff calls for high traffic conditions at the cost of new calls.

\section{Acknowledgment}

The authors are greatful to the referees on their comments for the improvement of this paper. We have incorporated of their suggestions in this paper. One of the authors, Geetanjali Sharma, gratefully acknowledges the financial support provided by the Department of Sciences and Technology (DST), Government of India for carrying out this research at Centre for Mathematical Sciences in Banasthali University.

\section{References}

[1] Amin, M.R. and Islam, Md. I., "Evaluation of Delay of Voice End User in Cellular Mobile Networks with 2D Traffic System", Research Journal of Information Technology, 1(2): 5769 (2009).

[2] Beaubrun, R., Pierre, S. and Conan, J., "Analysis of Traffic Distribution and Blocking Probability in Future Wireless Networks", International Journal of Wireless Information Networks, 14(1): March (2007).

[3] Choi, S. and Shin, K.G., "Adaptive Bandwidth Reservation and Admission Control in QOSSensitive Cellular Networks", IEEE Transactions on Parallel and Distributed Systems, 13: 882-897 (2002).

[4] Gavish, B. and Sridhar, S., "Threshold Priority Policy for Channel Assignment in Cellular Networks", IEEE Transaction on Computers, 46(3): 367-370 (1997).

[5] Guerrero, L.O. and Aghvami, A.H., "A Prioritized Handoff Dynamic Channel Allocation Strategy for PCS”, IEEE Transaction on Vehicular Technology, 48(4): 1203-1214 (1999). 
[6] Hong, D. and Rappaport, S.S., "Traffic Model and Performance Analysis for Cellular Mobile Radio Telephone System with Prioritized and Non-prioritized Handoff Procedures", IEEE Transactions on Vehicular Technology, 33(3): 77-92 (1986).

[7] Jain, M. and Rakhee, "A Subrating Channel Assignment Scheme for Cellular Radio Network with Directed Retry", Computers and Operations Research, 32: 2407-2417 (2005).

[8] Kleinrock, L., "Queueing Systems", Vol. II, Computer Applications, Wiley-Interscience.

[9] Li, W. and Alpha, A.S., "A PCS Network with Correlated Arrival Process and Splitted-rating Channels", IEEE Transaction on Selected Areas in Communication, 17(7): 1318-25 (1999).

[10] Lin, P. and Lin, Y.B., "Channel Assignment for GSM Half-rate and Full-rate Traffic", Computer Communication, 23: 476-482 (2000).

[11] Lin, Y.B., Anthony and Harasty, D., "The Subrating Channel Assignment Strategy for PCS Handoff", IEEE Transactions on Vehicular Technology, 45(1): 122-130 (1996).

[12] Li, X.J. and Joo, P.H., "Performance Analysis of Multihop Cellular Network with fixed Channe Assignment", Wireless Network, DOI 10.1007/s11276-008-0150-1.

[13] Louvros, S., Pylarinos, J. and Kotsopoulos, S., "Mean Waiting Time Analysis in Finite Storage Queues for Wireless Cellular Networks", Wireless Personal Communications: An International Journal, 40(2): 145-155 (2007).

[14] Louvros, S., Pylarinos, J. and Kotsopoulos, S., "Handoff Multiple Queue Model in Microcellular Networks", Computer Communications, 30: 396-403 (2007).

[15] Milosh, I., Moshe, Z., Paul, F. and Maxim, G., "Performance between Circuit Allocation Schemes for Half and Full-rate Connections in GSM", IEEE Transaction on Vehicular Technology, 47(3): 790-797 (1998).

[16] Ojesanmi, O.A. ,Ojesanmi, A. and Makinde, O., "Development of Prioritized Handoff Scheme for Congestion Control in Multimedia wireless Network", WCE 2009, Vol. I., July (2009).

[17] Tekinary, S. and Jabbary, B., "Handover and Channel Assignment in Mobile Cellular Networks", IEEE Communications Magazine, 29(11): 42-46 (1991).

[18] Ye, Z., Law, L.K., Krishnamurthy, S.V., Xu, Z., Dhirakaosal, S., Tripathi, S.K. and Molle, M.L., "Predictive Channel Reservation for handoff prioritization in Wireless Cellular Networks", Computer Networks, (2006). 


\section{Appendix I}

Table 1.

\begin{tabular}{|l|l|l|l|}
\hline $\mathrm{C}=21$ & $\mathrm{Ch}=3$ & $\mathrm{~K}=3$ & $\lambda_{\mathrm{nv}}=0.3$ \\
\hline$\mu_{\mathrm{H}}=0.01$ & $\mu_{\mathrm{Q}}=.005$ & & \\
\hline & Model-I $\left(\mathrm{P}_{\mathrm{B}}\right)$ & Model-II $\left(\mathrm{P}_{\mathrm{B}}\right)$ & Model-III $\left(\mathrm{P}_{\mathrm{B}}\right)$ \\
\hline$\lambda_{\text {nd }}=0.0$ & 0.609 & 0.692 & 0.901 \\
\hline$\lambda_{\mathrm{nd}}=0.2$ & 0.759 & 0.807 & 0.940 \\
\hline$\lambda_{\text {nd }}=0.4$ & 0.827 & 0.859 & 0.957 \\
\hline$\lambda_{\text {nd }}=0.6$ & 0.865 & 0.889 & 0.967 \\
\hline$\lambda_{\text {nd }}=0.8$ & 0.889 & 0.909 & 0.973 \\
\hline$\lambda_{\text {nd }}=1.0$ & 0.906 & 0.923 & 0.977 \\
\hline
\end{tabular}

Table 2.

\begin{tabular}{|l|l|l|l|}
\hline $\mathrm{C}=21$ & $\mathrm{Ch}=3$ & $\mathrm{~K}=3$ & $\lambda_{\mathrm{nv}}=0.3$ \\
\hline$\mu_{\mathrm{H}}=0.01$ & $\mu_{\mathrm{Q}}=.005$ & & \\
\hline & Model-I $\left(\mathrm{P}_{\text {fh }}\right)$ & Model-II $\left(\mathrm{P}_{\text {fh }}\right)$ & Model-III $\left(\mathrm{P}_{\text {fh }}\right)$ \\
\hline$\lambda_{\text {nd }}=0.0$ & 0.0002 & 0.016 & 0.0005 \\
\hline$\lambda_{\text {nd }}=0.2$ & 0.0004 & 0.025 & 0.0007 \\
\hline$\lambda_{\text {nd }}=0.4$ & 0.0006 & 0.030 & 0.0008 \\
\hline$\lambda_{\text {nd }}=0.6$ & 0.0007 & 0.033 & 0.001 \\
\hline$\lambda_{\text {nd }}=0.8$ & 0.0008 & 0.035 & 0.001 \\
\hline$\lambda_{\text {nd }}=1.0$ & 0.0008 & 0.036 & 0.001 \\
\hline
\end{tabular}

Table 3.

\begin{tabular}{|l|l|l|l|}
\hline $\mathrm{C}=21$ & $\mathrm{Ch}=3$ & $\mathrm{~K}=3$ & $\lambda_{\mathrm{nv}}=0.3$ \\
\hline$\mu_{\mathrm{H}}=0.01$ & $\mu_{\mathrm{Q}}=.005$ & & \\
\hline & Model-I $\left(\mathrm{P}_{\mathrm{F}}\right)$ & Model-II $\left(\mathrm{P}_{\mathrm{F}}\right)$ & Model-III $\left(\mathrm{P}_{\mathrm{F}}\right)$ \\
\hline$\lambda_{\text {nd }}=0.0$ & 0.0002 & 0.01 & 0.0003 \\
\hline$\lambda_{\text {nd }}=0.2$ & 0.0003 & 0.016 & 0.0005 \\
\hline$\lambda_{\text {nd }}=0.4$ & 0.0004 & 0.019 & 0.0005 \\
\hline$\lambda_{\text {nd }}=0.6$ & 0.0004 & 0.021 & 0.0006 \\
\hline$\lambda_{\text {nd }}=0.8$ & 0.0005 & 0.022 & 0.0006 \\
\hline$\lambda_{\text {nd }}=1.0$ & 0.0005 & 0.023 & 0.0006 \\
\hline
\end{tabular}


Table 4.

\begin{tabular}{|l|l|l|l|}
\hline $\mathrm{C}=21$ & $\mathrm{Ch}=3$ & $\mathrm{~K}=3$ & $\lambda_{\mathrm{nv}}=0.3$ \\
\hline$\mu_{\mathrm{H}}=0.01$ & $\mu_{\mathrm{Q}}=.005$ & & \\
\hline & Model-I $\left(\mathrm{P}_{\mathrm{nc}}\right)$ & Model-II $\left(\mathrm{P}_{\mathrm{nc}}\right)$ & Model-III $\left(\mathrm{P}_{\mathrm{nc}}\right)$ \\
\hline$\lambda_{\mathrm{nd}}=0.0$ & 0.609 & 0.695 & 0.731 \\
\hline$\lambda_{\mathrm{nd}}=0.2$ & 0.759 & 0.809 & 0.834 \\
\hline$\lambda_{\mathrm{nd}}=0.4$ & 0.827 & 0.862 & 0.877 \\
\hline$\lambda_{\mathrm{nd}}=0.6$ & 0.865 & 0.892 & 0.904 \\
\hline$\lambda_{\mathrm{nd}}=0.8$ & 0.889 & 0.911 & 0.921 \\
\hline$\lambda_{\mathrm{nd}}=1.0$ & 0.906 & 0.925 & 0.933 \\
\hline
\end{tabular}

Table 5.

\begin{tabular}{|l|l|l|l|}
\hline $\mathrm{C}=21$ & $\mathrm{Ch}=3$ & $\mathrm{~K}=3$ & $\lambda_{\mathrm{nd}}=0.2$ \\
\hline$\mu_{\mathrm{H}}=0.01$ & $\mu_{\mathrm{Q}}=.005$ & & \\
\hline & Model-I $\left(\mathrm{P}_{\mathrm{B}}\right)$ & Model-II $\left(\mathrm{P}_{\mathrm{B}}\right)$ & Model-III $\left(\mathrm{P}_{\mathrm{B}}\right)$ \\
\hline$\lambda_{\mathrm{nv}}=0.0$ & 0.438 & 0.798 & 0.852 \\
\hline$\lambda_{\mathrm{nv}}=0.2$ & 0.702 & 0.895 & 0.926 \\
\hline$\lambda_{\mathrm{nv}}=0.4$ & 0.798 & 0.929 & 0.95 \\
\hline$\lambda_{\mathrm{nv}}=0.6$ & 0.848 & 0.947 & 0.963 \\
\hline$\lambda_{\mathrm{nv}}=0.8$ & 0.877 & 0.957 & 0.97 \\
\hline$\lambda_{\mathrm{nv}}=1.0$ & 0.898 & 0.964 & 0.975 \\
\hline
\end{tabular}

Table 6.

\begin{tabular}{|l|l|l|l|}
\hline $\mathrm{C}=21$ & $\mathrm{Ch}=3$ & $\mathrm{~K}=3$ & $\lambda_{\mathrm{nd}}=0.2$ \\
\hline$\mu_{\mathrm{H}}=0.01$ & $\mu_{\mathrm{Q}}=.005$ & & \\
\hline & Model-I $\left(\mathrm{P}_{\mathrm{fh}}\right)$ & Model-II $\left(\mathrm{P}_{\mathrm{fh}}\right)$ & Model-III $\left(\mathrm{P}_{\mathrm{fh}}\right)$ \\
\hline$\lambda_{\mathrm{nv}}=0.0$ & 0.0004 & 0.024 & 0.0003 \\
\hline$\lambda_{\mathrm{nv}}=0.2$ & 0.0004 & 0.023 & 0.0007 \\
\hline$\lambda_{\mathrm{nv}}=0.4$ & 0.0004 & 0.022 & 0.0008 \\
\hline$\lambda_{\mathrm{nv}}=0.6$ & 0.0004 & 0.021 & 0.001 \\
\hline$\lambda_{\mathrm{nv}}=0.8$ & 0.0005 & 0.021 & 0.001 \\
\hline$\lambda_{\mathrm{nv}}=1.0$ & 0.0005 & 0.021 & 0.001 \\
\hline
\end{tabular}


Table 7.

\begin{tabular}{|l|l|l|l|}
\hline $\mathrm{C}=21$ & $\mathrm{Ch}=3$ & $\mathrm{~K}=3$ & $\lambda_{\mathrm{nd}}=0.2$ \\
\hline$\mu_{\mathrm{H}}=0.01$ & $\mu_{\mathrm{Q}}=.005$ & & \\
\hline & Model-I $\left(\mathrm{P}_{\mathrm{F}}\right)$ & Model-II $\left(\mathrm{P}_{\mathrm{F}}\right)$ & Model-III $\left(\mathrm{P}_{\mathrm{F}}\right)$ \\
\hline$\lambda_{\mathrm{nv}}=0.0$ & 0.0002 & 0.015 & 0.0002 \\
\hline$\lambda_{\mathrm{nv}}=0.2$ & 0.0003 & 0.014 & 0.0004 \\
\hline$\lambda_{\mathrm{nv}}=0.4$ & 0.0003 & 0.014 & 0.0005 \\
\hline$\lambda_{\mathrm{nv}}=0.6$ & 0.0003 & 0.014 & 0.0006 \\
\hline$\lambda_{\mathrm{nv}}=0.8$ & 0.0003 & 0.013 & 0.0006 \\
\hline$\lambda_{\mathrm{nv}}=1.0$ & 0.0003 & 0.013 & 0.0006 \\
\hline
\end{tabular}

Table 8.

\begin{tabular}{|l|l|l|l|}
\hline $\mathrm{C}=21$ & $\mathrm{Ch}=3$ & $\mathrm{~K}=3$ & $\lambda_{\mathrm{nd}}=0.2$ \\
\hline$\mu_{\mathrm{H}}=0.01$ & $\mu_{\mathrm{Q}}=.005$ & & \\
\hline & Model-I $\left(\mathrm{P}_{\mathrm{nc}}\right)$ & Model-II $\left(\mathrm{P}_{\mathrm{nc}}\right)$ & Model-III $\left(\mathrm{P}_{\mathrm{nc}}\right)$ \\
\hline$\lambda_{\mathrm{nv}}=0.0$ & 0.438 & 0.801 & 0.618 \\
\hline$\lambda_{\mathrm{nv}}=0.2$ & 0.702 & 0.897 & 0.793 \\
\hline$\lambda_{\mathrm{nv}}=0.4$ & 0.799 & 0.93 & 0.858 \\
\hline$\lambda_{\mathrm{nv}}=0.6$ & 0.848 & 0.948 & 0.892 \\
\hline$\lambda_{\mathrm{nv}}=0.8$ & 0.878 & 0.958 & 0.913 \\
\hline$\lambda_{\mathrm{nv}}=1.0$ & 0.898 & 0.965 & 0.927 \\
\hline
\end{tabular}




\section{Appendix II}

Table 1.

\begin{tabular}{|l|l|l|l|}
\hline $\mathrm{C}=21$ & $\mathrm{Ch}=3$ & $\mathrm{~K}=3$ & $\lambda_{\mathrm{nv}}=0.3$ \\
\hline$\mu_{\mathrm{H}}=0.025$ & $\mu_{\mathrm{O}}=.015$ & & \\
\hline & Model-I $\left(\mathrm{P}_{\mathrm{B}}\right)$ & Model-II $\left(\mathrm{P}_{\mathrm{B}}\right)$ & Model-III $\left(\mathrm{P}_{\mathrm{B}}\right)$ \\
\hline$\lambda_{\mathrm{nd}}=0.0$ & 0.209 & 0.692 & 0.773 \\
\hline$\lambda_{\mathrm{nd}}=0.2$ & 0.467 & 0.807 & 0.863 \\
\hline$\lambda_{\mathrm{nd}}=0.4$ & 0.607 & 0.859 & 0.902 \\
\hline$\lambda_{\mathrm{nd}}=0.6$ & 0.689 & 0.889 & 0.924 \\
\hline$\lambda_{\mathrm{nd}}=0.8$ & 0.743 & 0.909 & 0.937 \\
\hline$\lambda_{\mathrm{nd}}=1.0$ & 0.782 & 0.923 & 0.947 \\
\hline
\end{tabular}

Table 2.

\begin{tabular}{|l|l|l|l|}
\hline $\mathrm{C}=21$ & $\mathrm{Ch}=3$ & $\mathrm{~K}=3$ & $\lambda_{\mathrm{nv}}=0.3$ \\
\hline$\mu_{\mathrm{H}}=0.025$ & $\mu_{\mathrm{Q}}=.015$ & & \\
\hline & Model-I $\left(\mathrm{P}_{\mathrm{fh}}\right)$ & Model-II $\left(\mathrm{P}_{\mathrm{fh}}\right)$ & Model-III $\left(\mathrm{P}_{\mathrm{fh}}\right)$ \\
\hline$\lambda_{\mathrm{nd}}=0.0$ & 0 & 0.016 & 0.0003 \\
\hline$\lambda_{\mathrm{nd}}=0.2$ & 0.0004 & 0.025 & 0.0007 \\
\hline$\lambda_{\mathrm{nd}}=0.4$ & 0.0006 & 0.03 & 0.001 \\
\hline$\lambda_{\mathrm{nd}}=0.6$ & 0.0009 & 0.033 & 0.001 \\
\hline$\lambda_{\mathrm{nd}}=0.8$ & 0.001 & 0.035 & 0.001 \\
\hline$\lambda_{\mathrm{nd}}=1.0$ & 0.001 & 0.036 & 0.001 \\
\hline
\end{tabular}

Table 3.

\begin{tabular}{|l|l|l|l|}
\hline $\mathrm{C}=21$ & $\mathrm{Ch}=3$ & $\mathrm{~K}=3$ & $\lambda_{\mathrm{nv}}=0.3$ \\
\hline$\mu_{\mathrm{H}}=0.025$ & $\mu_{\mathrm{O}}=.015$ & & \\
\hline & Model-I $\left(\mathrm{P}_{\mathrm{F}}\right)$ & Model-II $\left(\mathrm{P}_{\mathrm{F}}\right)$ & Model-III $\left(\mathrm{P}_{\mathrm{F}}\right)$ \\
\hline$\lambda_{\mathrm{nd}}=0.0$ & 0.0001 & 0.01 & 0.0002 \\
\hline$\lambda_{\mathrm{nd}}=0.2$ & 0.0002 & 0.016 & 0.0005 \\
\hline$\lambda_{\mathrm{nd}}=0.4$ & 0.0004 & 0.019 & 0.0006 \\
\hline$\lambda_{\mathrm{nd}}=0.6$ & 0.0006 & 0.021 & 0.0008 \\
\hline$\lambda_{\mathrm{nd}}=0.8$ & 0.0007 & 0.022 & 0.0008 \\
\hline$\lambda_{\mathrm{nd}}=1.0$ & 0.0007 & 0.023 & 0.0009 \\
\hline
\end{tabular}


Table 4.

\begin{tabular}{|l|l|l|l|}
\hline $\mathrm{C}=21$ & $\mathrm{Ch}=3$ & $\mathrm{~K}=3$ & $\lambda_{\mathrm{nv}}=0.3$ \\
\hline$\mu_{\mathrm{H}}=0.025$ & $\mu_{\mathrm{Q}}=.015$ & & \\
\hline & Model-I $\left(\mathrm{P}_{\mathrm{nc}}\right)$ & Model-II $\left(\mathrm{P}_{\mathrm{nc}}\right)$ & Model-III $\left(\mathrm{P}_{\mathrm{nc}}\right)$ \\
\hline$\lambda_{\mathrm{nd}}=0.0$ & 0.209 & 0.695 & 0.463 \\
\hline$\lambda_{\mathrm{nd}}=0.2$ & 0.467 & 0.809 & 0.643 \\
\hline$\lambda_{\mathrm{nd}}=0.4$ & 0.607 & 0.862 & 0.734 \\
\hline$\lambda_{\mathrm{nd}}=0.6$ & 0.689 & 0.892 & 0.788 \\
\hline$\lambda_{\mathrm{nd}}=0.8$ & 0.744 & 0.911 & 0.824 \\
\hline$\lambda_{\mathrm{nd}}=1.0$ & 0.782 & 0.925 & 0.849 \\
\hline
\end{tabular}

Table 5.

\begin{tabular}{|l|l|l|l|}
\hline $\mathrm{C}=21$ & $\mathrm{Ch}=3$ & $\mathrm{~K}=3$ & $\lambda_{\mathrm{nd}}=0.2$ \\
\hline$\mu_{\mathrm{H}}=0.025$ & $\mu_{\mathrm{Q}}=.015$ & & \\
\hline & Model-I $\left(\mathrm{P}_{\mathrm{B}}\right)$ & Model-II $\left(\mathrm{P}_{\mathrm{B}}\right)$ & Model-III $\left(\mathrm{P}_{\mathrm{B}}\right)$ \\
\hline$\lambda_{\mathrm{nv}}=0.0$ & 0.046 & 0.567 & 0.662 \\
\hline$\lambda_{\mathrm{nv}}=0.2$ & 0.358 & 0.763 & 0.829 \\
\hline$\lambda_{\mathrm{nv}}=0.4$ & 0.547 & 0.837 & 0.886 \\
\hline$\lambda_{\mathrm{nv}}=0.6$ & 0.652 & 0.876 & 0.914 \\
\hline$\lambda_{\mathrm{nv}}=0.8$ & 0.718 & 0.90010341 & 0.931 \\
\hline$\lambda_{\mathrm{nv}}=1.0$ & 0.763 & 0.916 & 0.943 \\
\hline
\end{tabular}

Table 6.

\begin{tabular}{|l|l|l|l|}
\hline $\mathrm{C}=21$ & $\mathrm{Ch}=3$ & $\mathrm{~K}=3$ & $\lambda_{\mathrm{nd}}=0.2$ \\
\hline$\mu_{\mathrm{H}}=0.025$ & $\mu_{\mathrm{Q}}=.015$ & & \\
\hline & Model-I $\left(\mathrm{P}_{\mathrm{fh}}\right)$ & Model-II $\left(\mathrm{P}_{\mathrm{fh}}\right)$ & Model-III $\left(\mathrm{P}_{\mathrm{fh}}\right)$ \\
\hline$\lambda_{\mathrm{nv}}=0.0$ & 0.0001 & 0.019 & 0 \\
\hline$\lambda_{\mathrm{nv}}=0.2$ & 0.0005 & 0.025 & 0.0003 \\
\hline$\lambda_{\mathrm{nv}}=0.4$ & 0.001 & 0.027 & 0.0005 \\
\hline$\lambda_{\mathrm{nv}}=0.6$ & 0.001 & 0.026 & 0.0005 \\
\hline$\lambda_{\mathrm{nv}}=0.8$ & 0.001 & 0.026 & 0.0008 \\
\hline$\lambda_{\mathrm{nv}}=1.0$ & 0.001 & 0.026 & 0.0006 \\
\hline
\end{tabular}


Table 7.

\begin{tabular}{|l|l|l|l|}
\hline $\mathrm{C}=21$ & $\mathrm{Ch}=3$ & $\mathrm{~K}=3$ & $\lambda_{\mathrm{nd}}=0.2$ \\
\hline$\mu_{\mathrm{H}}=0.025$ & $\mu_{\mathrm{Q}}=.015$ & & \\
\hline & Model-I $\left(\mathrm{P}_{\mathrm{F}}\right)$ & Model-II $\left(\mathrm{P}_{\mathrm{F}}\right)$ & Model-III $\left(\mathrm{P}_{\mathrm{F}}\right)$ \\
\hline$\lambda_{\mathrm{nv}}=0.0$ & 0 & 0.012 & 0.0001 \\
\hline$\lambda_{\mathrm{nv}}=0.2$ & 0.0002 & 0.016 & 0.0003 \\
\hline$\lambda_{\mathrm{nv}}=0.4$ & 0.0003 & 0.016 & 0.001 \\
\hline$\lambda_{\mathrm{nv}}=0.6$ & 0.0003 & 0.016 & 0.001 \\
\hline$\lambda_{\mathrm{nv}}=0.8$ & 0.0004 & 0.016 & 0.001 \\
\hline$\lambda_{\mathrm{nv}}=1.0$ & 0.0004 & 0.017 & 0.001 \\
\hline
\end{tabular}

Table 8.

\begin{tabular}{|l|l|l|l|}
\hline $\mathrm{C}=21$ & $\mathrm{Ch}=3$ & $\mathrm{~K}=3$ & $\lambda_{\mathrm{nd}}=0.2$ \\
\hline$\mu_{\mathrm{H}}=0.025$ & $\mu_{\mathrm{Q}}=.015$ & & \\
\hline & Model-I $\left(\mathrm{P}_{\mathrm{nc}}\right)$ & Model-II $\left(\mathrm{P}_{\mathrm{nc}}\right)$ & Model-III $\left(\mathrm{P}_{\mathrm{nc}}\right)$ \\
\hline$\lambda_{\mathrm{nv}}=0.0$ & 0.046 & 0.573 & 0.291 \\
\hline$\lambda_{\mathrm{nv}}=0.2$ & 0.359 & 0.766 & 0.571 \\
\hline$\lambda_{\mathrm{nv}}=0.4$ & 0.547 & 0.839 & 0.695 \\
\hline$\lambda_{\mathrm{nv}}=0.6$ & 0.652 & 0.878 & 0.764 \\
\hline$\lambda_{\mathrm{nv}}=0.8$ & 0.719 & 0.902 & 0.807 \\
\hline$\lambda_{\mathrm{nv}}=1.0$ & 0.764 & 0.918 & 0.837 \\
\hline
\end{tabular}




\section{Appendix III}

Table 1.

\begin{tabular}{|l|l|l|l|}
\hline $\mathrm{C}=21$ & $\mathrm{Ch}=3$ & $\mathrm{~K}=9$ & $\lambda_{\mathrm{nv}}=0.3$ \\
\hline$\mu_{\mathrm{H}}=0.01$ & $\mu_{\mathrm{Q}}=.005$ & & \\
\hline & Model-I $\left(\mathrm{P}_{\mathrm{B}}\right)$ & Model-II $\left(\mathrm{P}_{\mathrm{B}}\right)$ & Model-III $\left(\mathrm{P}_{\mathrm{B}}\right)$ \\
\hline$\lambda_{\mathrm{nd}}=0.0$ & 0.609 & 0.861 & 0.901 \\
\hline$\lambda_{\mathrm{nd}}=0.2$ & 0.76 & 0.916 & 0.942 \\
\hline$\lambda_{\mathrm{nd}}=0.4$ & 0.827 & 0.939 & 0.959 \\
\hline$\lambda_{\mathrm{nd}}=0.6$ & 0.865 & 0.953 & 0.968 \\
\hline$\lambda_{\mathrm{nd}}=0.8$ & 0.889 & 0.961 & 0.974 \\
\hline$\lambda_{\mathrm{nd}}=1.0$ & 0.906 & 0.967 & 0.978 \\
\hline
\end{tabular}

Table 2.

\begin{tabular}{|l|l|l|l|}
\hline $\mathrm{C}=21$ & $\mathrm{Ch}=3$ & $\mathrm{~K}=9$ & $\lambda_{\mathrm{nv}}=0.3$ \\
\hline$\mu_{\mathrm{H}}=0.01$ & $\mu_{\mathrm{Q}}=.005$ & & \\
\hline & Model-I $\left(\mathrm{P}_{\mathrm{fh}}\right)$ & Model-II $\left(\mathrm{P}_{\mathrm{fh}}\right)$ & Model-III $\left(\mathrm{P}_{\mathrm{fh}}\right)$ \\
\hline$\lambda_{\mathrm{nd}}=0.0$ & 0.0003 & 0.016 & 0.001 \\
\hline$\lambda_{\mathrm{nd}}=0.2$ & 0.0004 & 0.018 & 0.001 \\
\hline$\lambda_{\mathrm{nd}}=0.4$ & 0.001 & 0.019 & 0.001 \\
\hline$\lambda_{\mathrm{nd}}=0.6$ & 0.001 & 0.02 & 0.001 \\
\hline$\lambda_{\mathrm{nd}}=0.8$ & 0.001 & 0.02 & 0.001 \\
\hline$\lambda_{\mathrm{nd}}=1.0$ & 0.001 & 0.021 & 0.001 \\
\hline
\end{tabular}

Table 3.

\begin{tabular}{|l|l|l|l|}
\hline $\mathrm{C}=21$ & $\mathrm{Ch}=3$ & $\mathrm{~K}=9$ & $\lambda_{\mathrm{nv}}=0.3$ \\
\hline$\mu_{\mathrm{H}}=0.01$ & $\mu_{\mathrm{Q}}=.005$ & & \\
\hline & Model-I $\left(\mathrm{P}_{\mathrm{F}}\right)$ & Model-II $\left(\mathrm{P}_{\mathrm{F}}\right)$ & Model-III $\left(\mathrm{P}_{\mathrm{F}}\right)$ \\
\hline$\lambda_{\text {nd }}=0.0$ & 0.0002 & 0.01 & 0.0004 \\
\hline$\lambda_{\text {nd }}=0.2$ & 0.0003 & 0.012 & 0.0006 \\
\hline$\lambda_{\text {nd }}=0.4$ & 0.0003 & 0.012 & 0.001 \\
\hline$\lambda_{\text {nd }}=0.6$ & 0.0004 & 0.013 & 0.001 \\
\hline$\lambda_{\mathrm{nd}}=0.8$ & 0.0004 & 0.013 & 0.001 \\
\hline$\lambda_{\mathrm{nd}}=1.0$ & 0.0004 & 0.013 & 0.001 \\
\hline
\end{tabular}


Table 4.

\begin{tabular}{|l|l|l|l|}
\hline $\mathrm{C}=21$ & $\mathrm{Ch}=3$ & $\mathrm{~K}=9$ & $\lambda_{\mathrm{nv}}=0.3$ \\
\hline$\mu_{\mathrm{H}}=0.01$ & $\mu_{\mathrm{Q}}=.005$ & & \\
\hline & Model-I $\left(\mathrm{P}_{\mathrm{nc}}\right)$ & Model-II $\left(\mathrm{P}_{\mathrm{nc}}\right)$ & Model-III $\left(\mathrm{P}_{\mathrm{nc}}\right)$ \\
\hline$\lambda_{\mathrm{nd}}=0.0$ & 0.609 & 0.863 & 0.731 \\
\hline$\lambda_{\mathrm{nd}}=0.2$ & 0.76 & 0.917 & 0.835 \\
\hline$\lambda_{\mathrm{nd}}=0.4$ & 0.827 & 0.94 & 0.881 \\
\hline$\lambda_{\mathrm{nd}}=0.6$ & 0.865 & 0.954 & 0.907 \\
\hline$\lambda_{\mathrm{nd}}=0.8$ & 0.889 & 0.962 & 0.924 \\
\hline$\lambda_{\mathrm{nd}}=1.0$ & 0.906 & 0.968 & 0.936 \\
\hline
\end{tabular}

Table 5.

\begin{tabular}{|l|l|l|l|}
\hline $\mathrm{C}=21$ & $\mathrm{Ch}=3$ & $\mathrm{~K}=9$ & $\lambda_{\mathrm{nd}}=0.2$ \\
\hline$\mu_{\mathrm{H}}=0.01$ & $\mu_{\mathrm{Q}}=.005$ & & \\
\hline & Model-I $\left(\mathrm{P}_{\mathrm{B}}\right)$ & Model-II $\left(\mathrm{P}_{\mathrm{B}}\right)$ & Model-III $\left(\mathrm{P}_{\mathrm{B}}\right)$ \\
\hline$\lambda_{\mathrm{nv}}=0.0$ & 0.438 & 0.799 & 0.858 \\
\hline$\lambda_{\mathrm{nv}}=0.2$ & 0.702 & 0.896 & 0.927 \\
\hline$\lambda_{\mathrm{nv}}=0.4$ & 0.799 & 0.93 & 0.951 \\
\hline$\lambda_{\mathrm{nv}}=0.6$ & 0.847 & 0.947 & 0.963 \\
\hline$\lambda_{\mathrm{nv}}=0.8$ & 0.878 & 0.957 & 0.97 \\
\hline$\lambda_{\mathrm{nv}}=1.0$ & 0.898 & 0.964 & 0.975 \\
\hline
\end{tabular}

Table 6.

\begin{tabular}{|l|l|l|l|}
\hline $\mathrm{C}=21$ & $\mathrm{Ch}=3$ & $\mathrm{~K}=9$ & $\lambda_{\mathrm{nd}}=0.2$ \\
\hline$\mu_{\mathrm{H}}=0.01$ & $\mu_{\mathrm{O}}=.005$ & & \\
\hline & Model-I $\left(\mathrm{P}_{\mathrm{fh}}\right)$ & Model-II $\left(\mathrm{P}_{\mathrm{fh}}\right)$ & Model-III $\left(\mathrm{P}_{\mathrm{fh}}\right)$ \\
\hline$\lambda_{\mathrm{nv}}=0.0$ & 0.0003 & 0.017 & 0.0006 \\
\hline$\lambda_{\mathrm{nv}}=0.2$ & 0.0004 & 0.018 & 0.0008 \\
\hline$\lambda_{\mathrm{nv}}=0.4$ & 0.0004 & 0.018 & 0.001 \\
\hline$\lambda_{\mathrm{nv}}=0.6$ & 0.0004 & 0.019 & 0.001 \\
\hline$\lambda_{\mathrm{nv}}=0.8$ & 0.0004 & 0.019 & 0.001 \\
\hline$\lambda_{\mathrm{nv}}=1.0$ & 0.0005 & 0.019 & 0.001 \\
\hline
\end{tabular}


Table 7.

\begin{tabular}{|l|l|l|l|}
\hline $\mathrm{C}=21$ & $\mathrm{Ch}=3$ & $\mathrm{~K}=9$ & $\lambda_{\mathrm{nd}}=0.2$ \\
\hline$\mu_{\mathrm{H}}=0.01$ & $\mu_{\mathrm{O}}=.005$ & & \\
\hline & Model-I $\left(\mathrm{P}_{\mathrm{F}}\right)$ & Model-II $\left(\mathrm{P}_{\mathrm{F}}\right)$ & Model-III $\left(\mathrm{P}_{\mathrm{F}}\right)$ \\
\hline$\lambda_{\mathrm{nv}}=0.0$ & 0.0002 & 0.011 & 0.0004 \\
\hline$\lambda_{\mathrm{nv}}=0.2$ & 0.0003 & 0.011 & 0.0005 \\
\hline$\lambda_{\mathrm{nv}}=0.4$ & 0.0003 & 0.012 & 0.0006 \\
\hline$\lambda_{\mathrm{nv}}=0.6$ & 0.0003 & 0.012 & 0.0006 \\
\hline$\lambda_{\mathrm{nv}}=0.8$ & 0.0003 & 0.012 & 0.001 \\
\hline$\lambda_{\mathrm{nv}}=1.0$ & 0.0003 & 0.012 & 0.001 \\
\hline
\end{tabular}

Table 8.

\begin{tabular}{|l|l|l|l|}
\hline $\mathrm{C}=21$ & $\mathrm{Ch}=3$ & $\mathrm{~K}=9$ & $\lambda_{\mathrm{nd}}=0.2$ \\
\hline$\mu_{\mathrm{H}}=0.01$ & $\mu_{\mathrm{Q}}=.005$ & & \\
\hline & Model-I $\left(\mathrm{P}_{\mathrm{nc}}\right)$ & Model-II $\left(\mathrm{P}_{\mathrm{nc}}\right)$ & Model-III $\left(\mathrm{P}_{\mathrm{nc}}\right)$ \\
\hline$\lambda_{\mathrm{nv}}=0.0$ & 0.438 & 0.801 & 0.632 \\
\hline$\lambda_{\mathrm{nv}}=0.2$ & 0.702 & 0.897 & 0.798 \\
\hline$\lambda_{\mathrm{nv}}=0.4$ & 0.798 & 0.93 & 0.861 \\
\hline$\lambda_{\mathrm{nv}}=0.6$ & 0.848 & 0.947 & 0.894 \\
\hline$\lambda_{\mathrm{nv}}=0.8$ & 0.878 & 0.958 & 0.914 \\
$\lambda_{\mathrm{nv}}=1.0$ & 0.898 & 0.965 & 0.928 \\
\hline
\end{tabular}




\section{Appendix IV}

Table 1.

\begin{tabular}{|l|l|l|l|}
\hline $\mathrm{C}=21$ & $\mathrm{Ch}=3$ & $\mathrm{~K}=9$ & $\lambda_{\mathrm{nv}}=0.3$ \\
\hline$\mu_{\mathrm{H}}=0.025$ & $\mu_{\mathrm{O}}=.015$ & & \\
\hline & Model-I $\left(\mathrm{P}_{\mathrm{B}}\right)$ & Model-II $\left(\mathrm{P}_{\mathrm{B}}\right)$ & Model-III $\left(\mathrm{P}_{\mathrm{B}}\right)$ \\
\hline$\lambda_{\text {nd }}=0.0$ & 0.209 & 0.692 & 0.773 \\
\hline$\lambda_{\text {nd }}=0.2$ & 0.467 & 0.807 & 0.866 \\
\hline$\lambda_{\text {nd }}=0.4$ & 0.607 & 0.86 & 0.905 \\
\hline$\lambda_{\text {nd }}=0.6$ & 0.689 & 0.89 & 0.927 \\
\hline$\lambda_{\text {nd }}=0.8$ & 0.744 & 0.91 & 0.94 \\
\hline$\lambda_{\text {nd }}=1.0$ & 0.782 & 0.923 & 0.95 \\
\hline
\end{tabular}

Table 2.

\begin{tabular}{|l|l|l|l|}
\hline $\mathrm{C}=21$ & $\mathrm{Ch}=3$ & $\mathrm{~K}=9$ & $\lambda_{\mathrm{nv}}=0.3$ \\
\hline$\mu_{\mathrm{H}}=0.025$ & $\mu_{\mathrm{Q}}=.015$ & & \\
\hline & Model-I $\left(\mathrm{P}_{\mathrm{fh}}\right)$ & Model-II $\left(\mathrm{P}_{\mathrm{fh}}\right)$ & Model-III $\left(\mathrm{P}_{\mathrm{fh}}\right)$ \\
\hline$\lambda_{\mathrm{nd}}=0.0$ & 0.0001 & 0.016 & 0.0003 \\
\hline$\lambda_{\mathrm{nd}}=0.2$ & 0.0004 & 0.021 & 0.001 \\
\hline$\lambda_{\mathrm{nd}}=0.4$ & 0.0006 & 0.023 & 0.001 \\
\hline$\lambda_{\mathrm{nd}}=0.6$ & 0.0007 & 0.025 & 0.002 \\
\hline$\lambda_{\mathrm{nd}}=0.8$ & 0.001 & 0.026 & 0.002 \\
\hline$\lambda_{\mathrm{nd}}=1.0$ & 0.001 & 0.026 & 0.002 \\
\hline
\end{tabular}

Table 3.

\begin{tabular}{|l|l|l|l|}
\hline $\mathrm{C}=21$ & $\mathrm{Ch}=3$ & $\mathrm{~K}=9$ & $\lambda_{\mathrm{nv}}=0.3$ \\
\hline$\mu_{\mathrm{H}}=0.025$ & $\mu_{\mathrm{Q}}=.015$ & & \\
\hline & Model-I $\left(\mathrm{P}_{\mathrm{F}}\right)$ & Model-II $\left(\mathrm{P}_{\mathrm{F}}\right)$ & Model-III $\left(\mathrm{P}_{\mathrm{F}}\right)$ \\
\hline$\lambda_{\mathrm{nd}}=0.0$ & 0.0001 & 0.01 & 0.0002 \\
\hline$\lambda_{\mathrm{nd}}=0.2$ & 0.0002 & 0.013 & 0.0006 \\
\hline$\lambda_{\mathrm{nd}}=0.4$ & 0.0004 & 0.015 & 0.001 \\
\hline$\lambda_{\mathrm{nd}}=0.6$ & 0.0005 & 0.016 & 0.001 \\
\hline$\lambda_{\mathrm{nd}}=0.8$ & 0.0005 & 0.016 & 0.001 \\
\hline$\lambda_{\mathrm{nd}}=1.0$ & 0.0006 & 0.017 & 0.001 \\
\hline
\end{tabular}


Table 4.

\begin{tabular}{|l|l|l|l|}
\hline $\mathrm{C}=21$ & $\mathrm{Ch}=3$ & $\mathrm{~K}=9$ & $\lambda_{\mathrm{nv}}=0.3$ \\
\hline$\mu_{\mathrm{H}}=0.025$ & $\mu_{\mathrm{Q}}=.015$ & & \\
\hline & $\begin{array}{l}\text { Model-I } \\
\left(\mathrm{P}_{\mathrm{F}}\right)\end{array}$ & Model-II $\left(\mathrm{P}_{\mathrm{F}}\right)$ & Model-III $\left(\mathrm{P}_{\mathrm{F}}\right)$ \\
\hline$\lambda_{\text {nd }}=0.0$ & 0.0001 & 0.01 & 0.0002 \\
\hline$\lambda_{\text {nd }}=0.2$ & 0.0002 & 0.013 & 0.0006 \\
\hline$\lambda_{\text {nd }}=0.4$ & 0.0004 & 0.015 & 0.001 \\
\hline$\lambda_{\text {nd }}=0.6$ & 0.0005 & 0.016 & 0.001 \\
\hline$\lambda_{\text {nd }}=0.8$ & 0.0005 & 0.016 & 0.001 \\
\hline$\lambda_{\text {nd }}=1.0$ & 0.0006 & 0.017 & 0.001 \\
\hline
\end{tabular}

Table 5.

\begin{tabular}{|l|l|l|l|}
\hline $\mathrm{C}=21$ & $\mathrm{Ch}=3$ & $\mathrm{~K}=9$ & $\lambda_{\mathrm{nd}}=0.2$ \\
\hline$\mu_{\mathrm{H}}=0.025$ & $\mu_{\mathrm{Q}}=.015$ & & \\
\hline & Model-I $\left(\mathrm{P}_{\mathrm{B}}\right)$ & Model-II $\left(\mathrm{P}_{\mathrm{B}}\right)$ & Model-III $\left(\mathrm{P}_{\mathrm{B}}\right)$ \\
\hline$\lambda_{\mathrm{nv}}=0.0$ & 0.046 & 0.569 & 0.672 \\
\hline$\lambda_{\mathrm{nv}}=0.2$ & 0.358 & 0.763 & 0.833 \\
\hline$\lambda_{\mathrm{nv}}=0.4$ & 0.547 & 0.837 & 0.888 \\
\hline$\lambda_{\mathrm{nv}}=0.6$ & 0.652 & 0.876 & 0.915 \\
\hline$\lambda_{\mathrm{nv}}=0.8$ & 0.718 & 0.9 & 0.932 \\
\hline$\lambda_{\mathrm{nv}}=1.0$ & 0.764 & 0.916 & 0.943 \\
\hline
\end{tabular}

Table 6.

\begin{tabular}{|l|l|l|l|}
\hline $\mathrm{C}=21$ & $\mathrm{Ch}=3$ & $\mathrm{~K}=9$ & $\lambda_{\mathrm{nd}}=0.2$ \\
\hline$\mu_{\mathrm{H}}=0.025$ & $\mu_{\mathrm{Q}}=.015$ & & \\
\hline & Model-I $\left(\mathrm{P}_{\mathrm{fh}}\right)$ & Model-II $\left(\mathrm{P}_{\mathrm{fh}}\right)$ & Model-III $\left(\mathrm{P}_{\mathrm{fh}}\right)$ \\
\hline$\lambda_{\mathrm{nv}}=0.0$ & 0 & 0.014 & 0.0002 \\
\hline$\lambda_{\mathrm{nv}}=0.2$ & 0.0003 & 0.02 & 0.0007 \\
\hline$\lambda_{\mathrm{nv}}=0.4$ & 0.0004 & 0.022 & 0.001 \\
\hline$\lambda_{\mathrm{nv}}=0.6$ & 0.001 & 0.023 & 0.001 \\
\hline$\lambda_{\mathrm{nv}}=0.8$ & 0.001 & 0.023 & 0.001 \\
\hline$\lambda_{\mathrm{nv}}=1.0$ & 0.001 & 0.024 & 0.001 \\
\hline
\end{tabular}


Table 7.

\begin{tabular}{|l|l|l|l|}
\hline $\mathrm{C}=21$ & $\mathrm{Ch}=3$ & $\mathrm{~K}=9$ & $\lambda_{\mathrm{nd}}=0.2$ \\
\hline$\mu_{\mathrm{H}}=0.025$ & $\mu_{\mathrm{Q}}=.015$ & & \\
\hline & Model-I $\left(\mathrm{P}_{\mathrm{F}}\right)$ & Model-II $\left(\mathrm{P}_{\mathrm{F}}\right)$ & Model-III $\left(\mathrm{P}_{\mathrm{F}}\right)$ \\
\hline$\lambda_{\mathrm{nv}}=0.0$ & 0 & 0.009 & 0.0001 \\
\hline$\lambda_{\mathrm{nv}}=0.2$ & 0.0001 & 0.012 & 0.0005 \\
\hline$\lambda_{\mathrm{nv}}=0.4$ & 0.0003 & 0.014 & 0.0007 \\
\hline$\lambda_{\mathrm{nv}}=0.6$ & 0.0003 & 0.014 & 0.001 \\
\hline$\lambda_{\mathrm{nv}}=0.8$ & 0.0004 & 0.015 & 0.001 \\
\hline$\lambda_{\mathrm{nv}}=1.0$ & 0.0004 & 0.015 & 0.001 \\
\hline
\end{tabular}

Table 8.

\begin{tabular}{|l|l|l|l|}
\hline $\mathrm{C}=21$ & $\mathrm{Ch}=3$ & $\mathrm{~K}=9$ & $\lambda_{\mathrm{nd}}=0.2$ \\
\hline$\mu_{\mathrm{H}}=0.025$ & $\mu_{\mathrm{Q}}=.015$ & & \\
\hline & Model-I $\left(\mathrm{P}_{\mathrm{nc}}\right)$ & Model-II $\left(\mathrm{P}_{\mathrm{nc}}\right)$ & Model-III $\left(\mathrm{P}_{\mathrm{nc}}\right)$ \\
\hline$\lambda_{\mathrm{nv}}=0.0$ & 0.046 & 0.573 & 0.304 \\
\hline$\lambda_{\mathrm{nv}}=0.2$ & 0.359 & 0.766 & 0.579 \\
\hline$\lambda_{\mathrm{nv}}=0.4$ & 0.547 & 0.839 & 0.699 \\
\hline$\lambda_{\mathrm{nv}}=0.6$ & 0.652 & 0.878 & 0.767 \\
\hline$\lambda_{\mathrm{nv}}=0.8$ & 0.719 & 0.902 & 0.809 \\
\hline$\lambda_{\mathrm{nv}}=1.0$ & 0.764 & 0.918 & 0.839 \\
\hline
\end{tabular}




\section{Appendix V}

Table 1.

\begin{tabular}{|l|l|l|l|}
\hline $\mathrm{C}=21$ & $\mathrm{Ch}=3$ & $\mathrm{~K}=12$ & $\lambda_{\mathrm{nv}}=0.3$ \\
\hline$\mu_{\mathrm{h}}=0.01$ & $\mu_{\mathrm{Q}}=.005$ & & \\
\hline & Model-I $\left(\mathrm{P}_{\mathrm{B}}\right)$ & Model-II $\left(\mathrm{P}_{\mathrm{B}}\right)$ & Model-III $\left(\mathrm{P}_{\mathrm{B}}\right)$ \\
\hline$\lambda_{\mathrm{nd}}=0.0$ & 0.609 & 0.861 & 0.901 \\
\hline$\lambda_{\mathrm{nd}}=0.2$ & 0.76 & 0.916 & 0.942 \\
\hline$\lambda_{\mathrm{nd}}=0.4$ & 0.827 & 0.94 & 0.959 \\
\hline$\lambda_{\mathrm{nd}}=0.6$ & 0.865 & 0.953 & 0.968 \\
\hline$\lambda_{\mathrm{nd}}=0.8$ & 0.889 & 0.961 & 0.974 \\
\hline$\lambda_{\mathrm{nd}}=1.0$ & 0.906 & 0.967 & 0.978 \\
\hline
\end{tabular}

Table 2.

\begin{tabular}{|l|l|l|l|}
\hline $\mathrm{C}=21$ & $\mathrm{Ch}=3$ & $\mathrm{~K}=12$ & $\lambda_{\mathrm{nv}}=0.3$ \\
\hline$\mu_{\mathrm{h}}=0.01$ & $\mu_{\mathrm{Q}}=.005$ & & \\
\hline & Model-I $\left(\mathrm{P}_{\text {fh }}\right)$ & Model-II $\left(\mathrm{P}_{\mathrm{fh}}\right)$ & Model-III $\left(\mathrm{P}_{\mathrm{fh}}\right)$ \\
\hline$\lambda_{\mathrm{nd}}=0.0$ & 0.0003 & 0.016 & 0.001 \\
\hline$\lambda_{\mathrm{nd}}=0.2$ & 0.0004 & 0.018 & 0.001 \\
\hline$\lambda_{\mathrm{nd}}=0.4$ & 0.0005 & 0.019 & 0.001 \\
\hline$\lambda_{\mathrm{nd}}=0.6$ & 0.0006 & 0.02 & 0.001 \\
\hline$\lambda_{\mathrm{nd}}=0.8$ & 0.0006 & 0.02 & 0.001 \\
\hline$\lambda_{\mathrm{nd}}=1.0$ & 0.0007 & 0.02 & 0.001 \\
\hline
\end{tabular}

Table 3.

\begin{tabular}{|l|l|l|l|}
\hline $\mathrm{C}=21$ & $\mathrm{Ch}=3$ & $\mathrm{~K}=12$ & $\lambda_{\mathrm{nv}}=0.3$ \\
\hline$\mu_{\mathrm{h}}=0.01$ & $\mu_{\mathrm{Q}}=.005$ & & \\
\hline & Model-I $\left(\mathrm{P}_{\mathrm{F}}\right)$ & Model-II $\left(\mathrm{P}_{\mathrm{F}}\right)$ & Model-III $\left(\mathrm{P}_{\mathrm{F}}\right)$ \\
\hline$\lambda_{\mathrm{nd}}=0.0$ & 0.0002 & 0.01 & 0.0004 \\
\hline$\lambda_{\mathrm{nd}}=0.2$ & 0.0003 & 0.012 & 0.0006 \\
\hline$\lambda_{\mathrm{nd}}=0.4$ & 0.0003 & 0.012 & 0.0007 \\
\hline$\lambda_{\mathrm{nd}}=0.6$ & 0.0004 & 0.013 & 0.0008 \\
\hline$\lambda_{\mathrm{nd}}=0.8$ & 0.0004 & 0.013 & 0.0008 \\
\hline$\lambda_{\mathrm{nd}}=1.0$ & 0.0004 & 0.013 & 0.0008 \\
\hline
\end{tabular}


Table 4.

\begin{tabular}{|l|l|l|l|}
\hline $\mathrm{C}=21$ & $\mathrm{Ch}=3$ & $\mathrm{~K}=12$ & $\lambda_{\mathrm{nv}}=0.3$ \\
\hline$\mu_{\mathrm{h}}=0.01$ & $\mu_{\mathrm{Q}}=.005$ & & \\
\hline & Model-I $\left(\mathrm{P}_{\mathrm{nc}}\right)$ & Model-II $\left(\mathrm{P}_{\mathrm{nc}}\right)$ & Model-III $\left(\mathrm{P}_{\mathrm{nc}}\right)$ \\
\hline$\lambda_{\mathrm{nd}}=0.0$ & 0.609 & 0.863 & 0.731 \\
\hline$\lambda_{\mathrm{nd}}=0.2$ & 0.759 & 0.917 & 0.835 \\
\hline$\lambda_{\mathrm{nd}}=0.4$ & 0.827 & 0.94 & 0.881 \\
\hline$\lambda_{\mathrm{nd}}=0.6$ & 0.865 & 0.954 & 0.908 \\
\hline$\lambda_{\mathrm{nd}}=0.8$ & 0.889 & 0.962 & 0.924 \\
\hline$\lambda_{\mathrm{nd}}=1.0$ & 0.906 & 0.968 & 0.936 \\
\hline
\end{tabular}

Table 5.

\begin{tabular}{|l|l|l|l|}
\hline $\mathrm{C}=21$ & $\mathrm{Ch}=3$ & $\mathrm{~K}=12$ & $\lambda_{\mathrm{nd}}=0.2$ \\
\hline$\mu_{\mathrm{h}}=0.01$ & $\mu_{\mathrm{Q}}=.005$ & & \\
\hline & Model-I $\left(\mathrm{P}_{\mathrm{B}}\right)$ & Model-II $\left(\mathrm{P}_{\mathrm{B}}\right)$ & Model-III $\left(\mathrm{P}_{\mathrm{B}}\right)$ \\
\hline$\lambda_{\mathrm{nv}}=0.0$ & 0.438 & 0.799 & 0.859 \\
\hline$\lambda_{\mathrm{nv}}=0.2$ & 0.702 & 0.896 & 0.927 \\
\hline$\lambda_{\mathrm{nv}}=0.4$ & 0.798 & 0.93 & 0.951 \\
\hline$\lambda_{\mathrm{nv}}=0.6$ & 0.848 & 0.947 & 0.963 \\
\hline$\lambda_{\mathrm{nv}}=0.8$ & 0.878 & 0.957 & 0.97 \\
\hline$\lambda_{\mathrm{nv}}=1.0$ & 0.898 & 0.964 & 0.975 \\
\hline
\end{tabular}

Table 6.

\begin{tabular}{|l|l|l|l|}
\hline $\mathrm{C}=21$ & $\mathrm{Ch}=3$ & $\mathrm{~K}=12$ & $\lambda_{\mathrm{nd}}=0.2$ \\
\hline$\mu_{\mathrm{h}}=0.01$ & $\mu_{\mathrm{O}}=.005$ & & \\
\hline & Model-I $\left(\mathrm{P}_{\mathrm{fh}}\right)$ & Model-II $\left(\mathrm{P}_{\mathrm{fh}}\right)$ & Model-III $\left(\mathrm{P}_{\mathrm{fh}}\right)$ \\
\hline$\lambda_{\mathrm{nv}}=0.0$ & 0.0003 & 0.016 & 0.001 \\
\hline$\lambda_{\mathrm{nv}}=0.2$ & 0.0004 & 0.018 & 0.001 \\
\hline$\lambda_{\mathrm{nv}}=0.4$ & 0.0004 & 0.018 & 0.001 \\
\hline$\lambda_{\mathrm{nv}}=0.6$ & 0.0004 & 0.019 & 0.001 \\
\hline$\lambda_{\mathrm{nv}}=0.8$ & 0.0005 & 0.019 & 0.001 \\
\hline$\lambda_{\mathrm{nv}}=1.0$ & 0.0005 & 0.019 & 0.001 \\
\hline
\end{tabular}


Table 7.

\begin{tabular}{|l|l|l|l|}
\hline $\mathrm{C}=21$ & $\mathrm{Ch}=3$ & $\mathrm{~K}=12$ & $\lambda_{\mathrm{nd}}=0.2$ \\
\hline$\mu_{\mathrm{h}}=0.01$ & $\mu_{\mathrm{Q}}=.005$ & & \\
\hline & Model-I $\left(\mathrm{P}_{\mathrm{F}}\right)$ & Model-II $\left(\mathrm{P}_{\mathrm{F}}\right)$ & Model-III $\left(\mathrm{P}_{\mathrm{F}}\right)$ \\
\hline$\lambda_{\mathrm{nv}}=0.0$ & 0.0002 & 0.01 & 0.0004 \\
\hline$\lambda_{\mathrm{nv}}=0.2$ & 0.0002 & 0.011 & 0.0005 \\
\hline$\lambda_{\mathrm{nv}}=0.4$ & 0.0003 & 0.012 & 0.0006 \\
\hline$\lambda_{\mathrm{nv}}=0.6$ & 0.0003 & 0.012 & 0.0006 \\
\hline$\lambda_{\mathrm{nv}}=0.8$ & 0.0003 & 0.012 & 0.0007 \\
\hline$\lambda_{\mathrm{nv}}=1.0$ & 0.0003 & 0.012 & 0.0007 \\
\hline
\end{tabular}

Table 8.

\begin{tabular}{|l|l|l|l|}
\hline $\mathrm{C}=21$ & $\mathrm{Ch}=3$ & $\mathrm{~K}=12$ & $\lambda_{\mathrm{nd}}=0.2$ \\
\hline$\mu_{\mathrm{h}}=0.01$ & $\mu_{\mathrm{Q}}=.005$ & & \\
\hline & Model-I $\left(\mathrm{P}_{\mathrm{nc}}\right)$ & Model-II $\left(\mathrm{P}_{\mathrm{nc}}\right)$ & Model-III $\left(\mathrm{P}_{\mathrm{nc}}\right)$ \\
\hline$\lambda_{\mathrm{nv}}=0.0$ & 0.438 & 0.801 & 0.633 \\
\hline$\lambda_{\mathrm{nv}}=0.2$ & 0.702 & 0.897 & 0.798 \\
\hline$\lambda_{\mathrm{nv}}=0.4$ & 0.798 & 0.93 & 0.861 \\
\hline$\lambda_{\mathrm{nv}}=0.6$ & 0.848 & 0.947 & 0.894 \\
\hline$\lambda_{\mathrm{nv}}=0.8$ & 0.878 & 0.958 & 0.914 \\
\hline$\lambda_{\mathrm{nv}}=1.0$ & 0.898 & 0.965 & 0.928 \\
\hline
\end{tabular}




\section{Appendix VI}

Table 1.

\begin{tabular}{|l|l|l|l|}
\hline $\mathrm{C}=21$ & $\mathrm{Ch}=3$ & $\mathrm{~K}=12$ & $\lambda_{\mathrm{nv}}=0.3$ \\
\hline$\mu_{\mathrm{h}}=0.025$ & $\mu_{\mathrm{Q}}=.015$ & & \\
\hline & Model-I $\left(\mathrm{P}_{\mathrm{B}}\right)$ & Model-II $\left(\mathrm{P}_{\mathrm{B}}\right)$ & Model-III $\left(\mathrm{P}_{\mathrm{B}}\right)$ \\
\hline$\lambda_{\mathrm{nd}}=0.0$ & 0.209 & 0.692 & 0.773 \\
\hline$\lambda_{\mathrm{nd}}=0.2$ & 0.467 & 0.807 & 0.866 \\
\hline$\lambda_{\mathrm{nd}}=0.4$ & 0.607 & 0.86 & 0.905 \\
\hline$\lambda_{\mathrm{nd}}=0.6$ & 0.689 & 0.89 & 0.927 \\
\hline$\lambda_{\mathrm{nd}}=0.8$ & 0.744 & 0.91 & 0.94 \\
\hline$\lambda_{\mathrm{nd}}=1.0$ & 0.782 & 0.923 & 0.95 \\
\hline
\end{tabular}

Table 2.

\begin{tabular}{|l|l|l|l|}
\hline $\mathrm{C}=21$ & $\mathrm{Ch}=3$ & $\mathrm{~K}=12$ & $\lambda_{\mathrm{nv}}=0.3$ \\
\hline$\mu_{\mathrm{h}}=0.025$ & $\mu_{\mathrm{O}}=.015$ & & \\
\hline & Model-I $\left(\mathrm{P}_{\mathrm{fh}}\right)$ & Model-II $\left(\mathrm{P}_{\mathrm{fh}}\right)$ & Model-III $\left(\mathrm{P}_{\mathrm{fh}}\right)$ \\
\hline$\lambda_{\mathrm{nd}}=0.0$ & 0.0001 & 0.016 & 0.0003 \\
\hline$\lambda_{\mathrm{nd}}=0.2$ & 0.0004 & 0.021 & 0.001 \\
\hline$\lambda_{\mathrm{nd}}=0.4$ & 0.0006 & 0.023 & 0.001 \\
\hline$\lambda_{\mathrm{nd}}=0.6$ & 0.0007 & 0.025 & 0.002 \\
\hline$\lambda_{\mathrm{nd}}=0.8$ & 0.0009 & 0.026 & 0.002 \\
\hline$\lambda_{\mathrm{nd}}=1.0$ & 0.001 & 0.026 & 0.002 \\
\hline
\end{tabular}

Table 3.

\begin{tabular}{|l|l|l|l|}
\hline $\mathrm{C}=21$ & $\mathrm{Ch}=3$ & $\mathrm{~K}=12$ & $\lambda_{\mathrm{nv}}=0.3$ \\
\hline$\mu_{\mathrm{h}}=0.025$ & $\mu_{\mathrm{Q}}=.015$ & & \\
\hline & Model-I $\left(\mathrm{P}_{\mathrm{F}}\right)$ & Model-II $\left(\mathrm{P}_{\mathrm{F}}\right)$ & Model-III $\left(\mathrm{P}_{\mathrm{F}}\right)$ \\
\hline$\lambda_{\mathrm{nd}}=0.0$ & 0 & 0.01 & 0.0002 \\
\hline$\lambda_{\mathrm{nd}}=0.2$ & 0.0002 & 0.013 & 0.0006 \\
\hline$\lambda_{\mathrm{nd}}=0.4$ & 0.0004 & 0.015 & 0.0008 \\
\hline$\lambda_{\mathrm{nd}}=0.6$ & 0.0005 & 0.016 & 0.001 \\
\hline$\lambda_{\mathrm{nd}}=0.8$ & 0.0005 & 0.016 & 0.001 \\
\hline$\lambda_{\mathrm{nd}}=1.0$ & 0.0006 & 0.017 & 0.001 \\
\hline
\end{tabular}


Table 4.

\begin{tabular}{|l|l|l|l|}
\hline $\mathrm{C}=21$ & $\mathrm{Ch}=3$ & $\mathrm{~K}=12$ & $\lambda_{\mathrm{nv}}=0.3$ \\
\hline$\mu_{\mathrm{h}}=0.025$ & $\mu_{\mathrm{Q}}=.015$ & & \\
\hline & Model-I $\left(\mathrm{P}_{\mathrm{nc}}\right)$ & Model-II $\left(\mathrm{P}_{\mathrm{nc}}\right)$ & Model-III $\left(\mathrm{P}_{\mathrm{nc}}\right)$ \\
\hline$\lambda_{\mathrm{nd}}=0.0$ & 0.209 & 0.695 & 0.463 \\
\hline$\lambda_{\mathrm{nd}}=0.2$ & 0.467 & 0.809 & 0.649 \\
\hline$\lambda_{\mathrm{nd}}=0.4$ & 0.607 & 0.862 & 0.742 \\
\hline$\lambda_{\mathrm{nd}}=0.6$ & 0.689 & 0.892 & 0.796 \\
\hline$\lambda_{\mathrm{nd}}=0.8$ & 0.744 & 0.911 & 0.832 \\
\hline$\lambda_{\mathrm{nd}}=1.0$ & 0.782 & 0.925 & 0.857 \\
\hline
\end{tabular}

Table 5.

\begin{tabular}{|l|l|l|l|}
\hline $\mathrm{C}=21$ & $\mathrm{Ch}=3$ & $\mathrm{~K}=12$ & $\lambda_{\mathrm{nd}}=0.2$ \\
\hline$\mu_{\mathrm{h}}=0.025$ & $\mu_{\mathrm{O}}=.015$ & & \\
\hline & Model-I $\left(\mathrm{P}_{\mathrm{B}}\right)$ & Model-II $\left(\mathrm{P}_{\mathrm{B}}\right)$ & Model-III $\left(\mathrm{P}_{\mathrm{B}}\right)$ \\
\hline$\lambda_{\mathrm{nv}}=0.0$ & 0.046 & 0.569 & 0.673 \\
\hline$\lambda_{\mathrm{nv}}=0.2$ & 0.358 & 0.763 & 0.833 \\
\hline$\lambda_{\mathrm{nv}}=0.4$ & 0.547 & 0.837 & 0.888 \\
\hline$\lambda_{\mathrm{nv}}=0.6$ & 0.652 & 0.876 & 0.915 \\
\hline$\lambda_{\mathrm{nv}}=0.8$ & 0.718 & 0.9 & 0.932 \\
\hline$\lambda_{\mathrm{nv}}=1.0$ & 0.764 & 0.916 & 0.943 \\
\hline
\end{tabular}

Table 6.

\begin{tabular}{|l|l|l|l|}
\hline $\mathrm{C}=21$ & $\mathrm{Ch}=3$ & $\mathrm{~K}=12$ & $\lambda_{\mathrm{nd}}=0.2$ \\
\hline$\mu_{\mathrm{h}}=0.025$ & $\mu_{\mathrm{Q}}=.015$ & & \\
\hline & Model-I $\left(\mathrm{P}_{\mathrm{fh}}\right)$ & Model-II $\left(\mathrm{P}_{\mathrm{fh}}\right)$ & Model-III $\left(\mathrm{P}_{\mathrm{fh}}\right)$ \\
\hline$\lambda_{\mathrm{nv}}=0.0$ & 0 & 0.014 & 0.0002 \\
\hline$\lambda_{\mathrm{nv}}=0.2$ & 0.0003 & 0.019 & 0.0007 \\
\hline$\lambda_{\mathrm{nv}}=0.4$ & 0.0004 & 0.022 & 0.001 \\
\hline$\lambda_{\mathrm{nv}}=0.6$ & 0.0005 & 0.023 & 0.001 \\
\hline$\lambda_{\mathrm{nv}}=0.8$ & 0.0006 & 0.023 & 0.001 \\
\hline$\lambda_{\mathrm{nv}}=1.0$ & 0.0006 & 0.024 & 0.001 \\
\hline
\end{tabular}


Table 7.

\begin{tabular}{|l|l|l|l|}
\hline $\mathrm{C}=21$ & $\mathrm{Ch}=3$ & $\mathrm{~K}=12$ & $\lambda_{\mathrm{nd}}=0.2$ \\
\hline$\mu_{\mathrm{h}}=0.025$ & $\mu_{\mathrm{Q}}=.015$ & & \\
\hline & Model-I $\left(\mathrm{P}_{\mathrm{F}}\right)$ & Model-II $\left(\mathrm{P}_{\mathrm{F}}\right)$ & Model-III $\left(\mathrm{P}_{\mathrm{F}}\right)$ \\
\hline$\lambda_{\mathrm{nv}}=0.0$ & 0 & 0.009 & 0.0001 \\
\hline$\lambda_{\mathrm{nv}}=0.2$ & 0.0002 & 0.012 & 0.0005 \\
\hline$\lambda_{\mathrm{nv}}=0.4$ & 0.0003 & 0.014 & 0.0007 \\
\hline$\lambda_{\mathrm{nv}}=0.6$ & 0.0003 & 0.014 & 0.0008 \\
\hline$\lambda_{\mathrm{nv}}=0.8$ & 0.0004 & 0.015 & 0.0009 \\
\hline$\lambda_{\mathrm{nv}}=1.0$ & 0.0004 & 0.015 & 0.0009 \\
\hline
\end{tabular}

Table 8.

\begin{tabular}{|l|l|l|l|}
\hline $\mathrm{C}=21$ & $\mathrm{Ch}=3$ & $\mathrm{~K}=12$ & $\lambda_{\mathrm{nd}}=0.2$ \\
\hline$\mu_{\mathrm{h}}=0.025$ & $\mu_{\mathrm{Q}}=.015$ & & \\
\hline & Model-I $\left(\mathrm{P}_{\mathrm{nc}}\right)$ & Model-II $\left(\mathrm{P}_{\mathrm{nc}}\right)$ & Model-III $\left(\mathrm{P}_{\mathrm{nc}}\right)$ \\
\hline$\lambda_{\mathrm{nv}}=0.0$ & 0.0456 & 0.573 & 0.304 \\
\hline$\lambda_{\mathrm{nv}}=0.2$ & 0.358 & 0.766 & 0.579 \\
\hline$\lambda_{\mathrm{nv}}=0.4$ & 0.547 & 0.839 & 0.699 \\
\hline$\lambda_{\mathrm{nv}}=0.6$ & 0.652 & 0.878 & 0.767 \\
\hline$\lambda_{\mathrm{nv}}=0.8$ & 0.719 & 0.902 & 0.809 \\
\hline$\lambda_{\mathrm{nv}}=1.0$ & 0.764 & 0.918 & 0.839 \\
\hline
\end{tabular}




\title{
تحليل نموذج الانتظار المتعدد في الثبكات الخلوية مع التصنيف الفرعي للقنوات
}

\author{
جيتانجالي شارما**، و ج.ن • بيروهيت* ، و راكدي

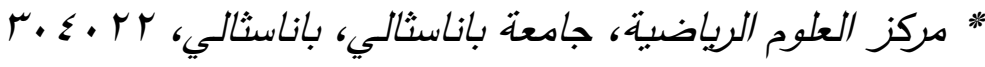

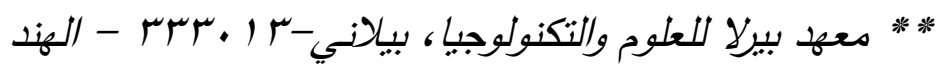

الستخلص. في الثبكات الخلوية يتم عامة اعتبار طابور انتظار واحد

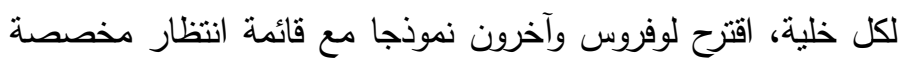

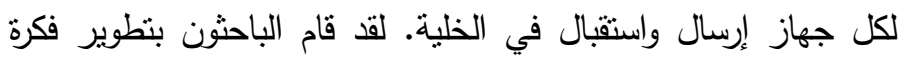

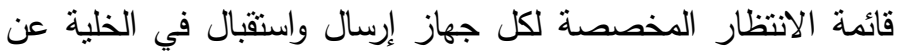
طريق التصنيف الفرعي للقنوات لتحسين جودة الخدمة بالنظام. تم في

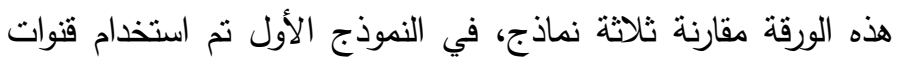

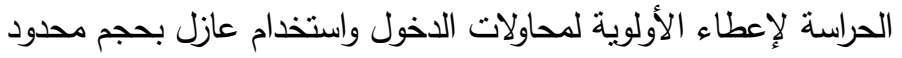

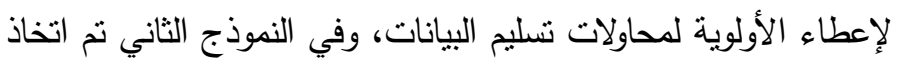

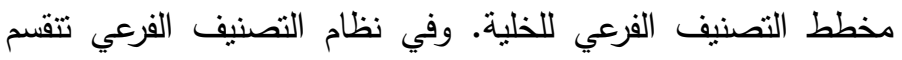

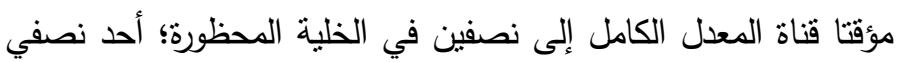

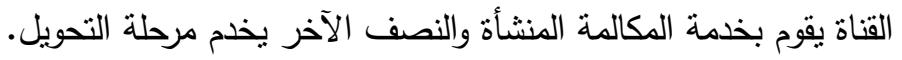
وقد اقترحنا قائمة انتظار مخصصة لكل جهاز إرسال واستقبال في الخلية

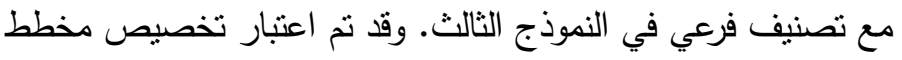

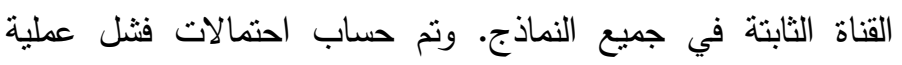
التحويل، ومنع مكالمات جديدة، والإنهاء القسري للمكالمات المحولة،

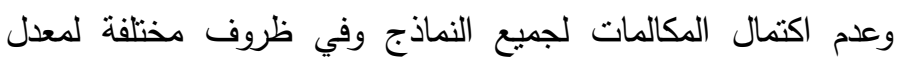

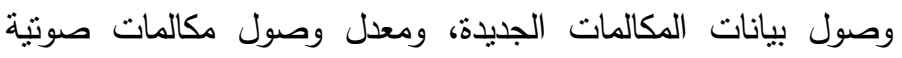

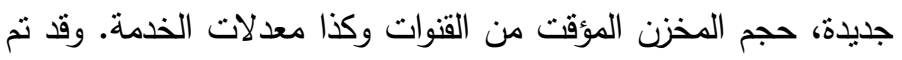
تحليل ومقارنة النتائج الرقمية للتحقق من صحة النماذج المقترحة. 